\title{
Poaceae de uma área de floresta montana no sul da Bahia, Brasil: Chloridoideae e Panicoideae ${ }^{1}$
}

Poaceae in a montane forest in the Southeastern Bahia, Brazil: Chloridoideae and Panicoideae

\author{
Aline Costa da Mota ${ }^{2,3}$ \& Reyjane Patrícia de Oliveira ${ }^{2}$
}

\begin{abstract}
Resumo
Foi realizado o levantamento das espécies pertencentes às subfamílias Chloridoideae e Panicoideae (Poaceae) em um remanescente de floresta montana (RPPN Serra Bonita), situado entre os municípios de Camacan e Pau Brasil, microrregião Litoral Sul da Bahia, bioma Mata Atlântica. Panicoideae está representada na área de estudos por 15 gêneros e 31 espécies, e Chloridoideae, por quatro espécies reunidas em três gêneros. Dichanthelium hebotes (Trin.) Zuloaga, Ocellochloa rudis (Nees) Zuloaga, Parodiophyllochloa cordovensis (E. Fourn.) Zuloaga \& Morrone e Urochloa arrecta (Hackel ex T. Durand \& Schinz) Morrone \& Zuloaga representam novos registros para a Bahia; Paspalum millegrana Schrad. e P. nutans Lam. estão sendo citadas pela primeira vez para uma área de floresta montana. São aqui apresentadas chaves de identificação para gêneros e espécies, além de descrições, ilustrações e comentários sobre as mesmas.
\end{abstract}

Palavras-chave: gramíneas, Mata Atlântica, sul da Bahia, Brasil.

\begin{abstract}
We present a survey of Chloridoideae and Panicoideae (Poaceae) in a remnant of montane forest (RPPN Serra Bonita), between Camacan and Pau Brasil municipalities, in the Southeastern of the Bahia State, Brazilian Atlantic Forest. Panicoideae includes 15 genera and 31 species in this area, and Chloridoideae, three genera and four species. Dichanthelium hebotes (Trin.) Zuloaga, Ocellochloa rudis (Nees) Zuloaga, Parodiophyllochloa cordovensis (E. Fourn.) Zuloaga \& Morrone and Urochloa arrecta (Hackel ex T. Durand \& Schinz) Morrone \& Zuloaga represent new records to Bahia; Paspalum millegrana Schrad. and $P$. nutans Lam. were recognized for the first time for a montane forest. Identification key for genera and species, descriptions and comments are provided for all of them.
\end{abstract}

Key-words: grasses, Atlantic Rain Forest, Southeastern Bahia, Brazil.

\section{Introdução}

O bioma Mata Atlântica é formado por uma estrutura vegetacional heterogênea e, de acordo com a "Lei da Mata Atlântica" de n 11.428 (Brasil 2006), integram as seguintes formações florestais e ecossistemas associados: floresta ombrófila densa, floresta ombrófila mista, floresta ombrófila aberta, floresta estacional semidecidual, floresta estacional decidual, manguezais, vegetações de restingas, campos de altitude, brejos interioranos e encraves florestais do Nordeste.
Na Bahia, a Mata Atlântica encontra-se distribuída em uma extensão de mais de $1.200 \mathrm{~km}$ no sentido norte-sul, sendo que, na região ao norte de Salvador, inclui apenas cerca de $260 \mathrm{~km}$, predominando as fisionomias de restingas e mangues (IBGE2004). Thomas (2003) indicou para o sul do Estado as seguintes formações associadas a este bioma: cordões de praia, mangues, restingas (restinga aberta, restinga inundada e floresta de restinga), florestas higrófilas (sobre planície latossólica, sobre planície podzólica, floresta

Este artigo possui material adicional em sua versão eletrônica.

\footnotetext{
${ }^{1}$ Parte da dissertação de Mestrado da primeira autora.

${ }^{2}$ Universidade Estadual de Feira de Santana, Depto. Ciências Biológicas, Programa de Pós-Graduação em Botânica, Av. Transnordestina s.n., 44036-460, Feira de Santana, BA, Brasil.

${ }^{3}$ Autor para correspondência: alinecostamota@gmail.com
} 
montana, floresta de tabuleiro e mussununga), além das florestas mesófilas (ou semidecíduas) e decíduas (floresta de cipó).

Dos biomas ocorrentes no Brasil, a Mata Atlântica tem sido o mais dizimado, restando apenas cerca de 7\% da sua cobertura original (SOS Mata Atlântica 2008). Para o sul da Bahia, estima-se que exista menos de $10 \%$ dessas florestas, as quais incluem, entretanto, os maiores remanescentes deste tipo florestal no Nordeste (Mori et al. 1983). Essa região possui áreas de extrema importância biológica (MMA 2000) e, em conjunto com as florestas do norte do Espírito Santo, detém altas taxas de diversidade florística, além de um grande número de espécies endêmicas. Estudos realizados nestas áreas florestais demonstraram endemismos em torno de $50 \%$, para plantas ocorrentes ao longo do bioma Mata Atlântica, das quais $30 \%$ apresentam endemismo local, restritas ao Sul da Bahia e norte do Espírito Santo (Thomas et al. 1998).

Grande parte dos levantamentos realizados até o momento nestas áreas se restringe às florestas submontanas e tabuleiros costeiros, e assim, áreas que apresentam contrafortes com até $1.000 \mathrm{~m}$ de altitude, correspondendo às florestas montanas, ainda são praticamente desconhecidas do ponto de vista florístico. Estas florestas ocorrem em áreas de relevo bastante acidentado, com altitudes variando entre 500 e $1000 \mathrm{~m}$, com precipitação anual de $1.300 \mathrm{~mm}$ e elevada umidade, apresentando-se exuberantes e com grande quantidade de epífitas e líquens (Thomas 2003).

Poaceae é uma das famílias mais diversas na Mata Atlântica da Bahia, especialmente por esta área ser considerada um grande centro de diversidade de bambus (Soderstrom et al. 1988; Oliveira et al. 2006). A maioria das espécies desta família ocorre em ambientes campestres. Além dos bambus, outros representantes são tipicamente florestais, às vezes citados como característicos das florestas neotropicais, como espécies dos gêneros Ichnanthus P. Beauv., Lasiacis (Griseb.) Hitchc., Panicum L. s.l., todos representantes da subfamília Panicoideae.

O presente trabalho apresenta o levantamento de duas subfamílias de Poaceae (Chloridoideae e Panicoideae) em um remanescente de floresta montana no Sul da Bahia (Serra Bonita), a fim de contribuir para o conhecimento da família ocorrente nas florestas do estado e fornecer subsídios para a manutenção desses remanescentes. Esses dados são complementares àqueles apresentados por Mota et al. (2009), que inclui o levantamento de outras duas subfamílias de Poaceae (Bambusoideae e Pharoideae), para a mesma área, além de uma chave para as subfamílias.

\section{Material e Métodos}

O presente levantamento foi realizado em uma área de floresta atlântica montana da Reserva Particular do Patrimônio Natural (RPPN) Serra Bonita, localizada entre os municípios de Camacan e Pau Brasil, na microrregião Litoral Sul da Bahia (coordenadas geográficas da sede: $15^{\circ} 23^{\prime} 30^{\prime \prime} \mathrm{S}$ e 39॰33'55'W).

Foram realizadas nove expedições para essa área, entre maio/2007 e abril/2008. As coletas ocorreram ao longo das trilhas principais que extendem-se pela floresta montana da RPPN, e a partir destas trilhas foram feitas coletas aleatórias, com intuito de abranger todas as fisionomias e microambientes. As expedições seguiram os procedimentos habituais, envolvendo coleta, prensagem, secagem e confecções de exsicatas (Mori et al.1989), e a análise dos materiais seguiu os métodos tradicionais em taxonomia, conforme descrito em Mota et al. (2009).

A terminologia utilizada para os caracteres morfológicos seguiu Longhi-Wagner et al. (2001). A identificação das subfamílias aqui tratadas pode ser obtida usando-se a chave de Mota et al. (2009).

Além das ilustrações apresentadas, fotos das espécies são anexadas ao final do artigo (ver Apêndice na versão eletrônica deste artigo).

\section{Resultados e Discussão}

Na floresta montana da RPPN Serra Bonita, foram encontradas quatro espécies de Chloridoideae, as quais ocorrem exclusivamente em áreas alteradas no entorno da floresta, e 31 espécies pertencentes à Panicoideae, das quais a maioria ocorre no interior, bordas ou clareiras da floresta, e apenas seis ocorrem exclusivamente em áreas alteradas em seu entorno.

\section{Chloridoideae}

Essa subfamília é dividida em três tribos (Columbus et al. 2007) e inclui ca. 150 gêneros e 1360 espécies distribuídas principalmente nas regiões áridas do globo (Hilu \& Alice 2001). Seus representantes caracterizam-se pelas lâminas foliares sésseis, espiguetas 1-plurifloras, basítonas, com ou sem antécios neutros apicais rudimentares e glumas persistentes após a queda dos antécios.

$\mathrm{Na}$ área de estudos foram registrados três gêneros e quatro espécies, dois deles pertencentes à tribo Cynodonteae (Chloris e Eleusine) e um à Zoysieae (Sporobolus). 


\section{Chave para os gêneros de Chloridoideae}

1. Espiguetas com lemas aristadas

1. Chloris

1'. Espiguetas com lemas múticos.

2. Inflorescências racemosas, ramos unilaterais espiciformes digitados a subdigitados; espiguetas com numerosos antécios

2'. Inflorescências paniculadas, ramos alternos, verticilados a subverticilados; espiguetas com um só antécio. 3. Sporobolus

1. Chloris Sw., Prodr. 1: 25. 1788.

Chloris possui ca. 40 espécies distribuídas nas regiões tropicais e subtropicais do globo (Longhi-Wagner 2001b). Possui inflorescências racemosas, com ramos unilaterais espiciformes verticilados no ápice do colmo florífero e espiguetas com o antécio inferior bissexuado, acompanhado de um a quatro antécios apicais neutros, desenvolvidos ou rudimentares, às vezes o segundo masculino, mais raramente bissexuado, e lemas aristados.

Renvoize (1984) citou seis espécies deste gênero para a Bahia, e na área de estudos, está representado por duas delas.

\section{Chave para as espécies de Chloris}

1. Plantas perenes, $25-85 \mathrm{~cm}$ alt.; lâminas foliares $6,5-19,5 \mathrm{~cm}$ compr., ápice subagudo; gluma inferior $1,8 \mathrm{~mm}$ compr; lema inferior com margens pilosas; lema superior $1-1,1 \mathrm{~mm}$ compr.

1.1. Chloris orthonoton

1'. Plantas anuais, ca. $15 \mathrm{~cm}$ alt.; lâminas foliares $0,8-2,7 \mathrm{~cm}$ compr., ápice obtuso; gluma inferior 0,9-1,4 mm compr.; lema inferior com margens escabras; lema superior ca. $0,2 \mathrm{~mm}$ compr.

1.2. Chloris pycnothrix

1.1 Chloris orthonoton Döll, Fl. Bras. 2(3): 64. 1878.

Fig. 1a

Plantas perenes, cespitoso-estoloníferas, 25$85 \mathrm{~cm}$ alt., entrenós e nós glabros. Folhas com bainhas glabras, margens glabras; lígula membranoso-ciliada, ca. 0,5 mm compr.; lâminas 6,5$19,5 \times 0,2-0,25 \mathrm{~cm}$, lineares, ápice subagudo, base reta, simétrica, face adaxial escabra, às vezes com tricomas longos esparsos, ou hirsuta na base, face abaxial glabra ou com tricomas longos esparsos, margens escabras, 6-8 nervuras secundárias. Inflorescências 3-13,5 cm compr., com 4-8 ramos unilaterais espiciformes verticilados a subverticilados, pedúnculos 7-20 cm compr., glabros, ráquis e pedicelos escabros, axilas pubescentes. Espiguetas solitárias, ca. $3 \mathrm{~mm}$ compr.; gluma inferior 1,8 mm compr., lanceolada, apiculada, escabras em toda a superfície ou apenas na nervura central, margens glabras, 1-nervada; gluma superior ca. 2,2 mm compr., arista ca. 0,8 mm compr., lanceolada, curto-aristada, escabra em toda a superfície ou apenas na nervura central, margens glabras, 1-nervada; lema inferior com flor bissexuada,
2,5-3 mm compr., arista 6,5-13 mm compr., oblanceolado, agudo, escabro, com tricomas na região mediana da nervura central, margens pilosas, 3-nervado; pálea inferior ca. 2,2 mm compr., oblanceolada, aguda, escabra, margens escabras, 2nervada; lema superior neutro, 1-1,1 mm compr., arista 3-6 mm compr., flabeliforme, retuso, escabro, margens escabras; pálea superior ausente. Frutos não analisados.

Material selecionado: trilha da torre, 24.XI.2007, fl., A.C. Mota 181 (HUEFS).

Esta espécie pode ser facilmente diferenciada de Chloris pycnothrix Trin., pelas plantas mais robustas, com lâminas foliares mais longas com ápice agudo versus plantas delicadas, com lâminas foliares de ápice obtuso.

No Brasil distribui-se do Rio Grande do Norte ao Rio Grande do Sul, em campos naturais ou locais perturbados como áreas cultivadas (LonghiWagner 2001b). Na área de estudos, suas touceiras ocorrem nas áreas alteradas no entorno da floresta, sob alta luminosidade. Foi coletada fértil no mês de novembro. 
1.2 Chloris pycnothrix Trin., Gram. unifl. sesquifl.: 234. 1824.

Fig. 1b-c

Plantas anuais, estoloníferas, ca. $15 \mathrm{~cm}$ alt., entrenós e nós glabros. Folhas com bainhas escabras na nervura central, margens glabras; lígula membranoso-ciliada, ca. 0,4 mm compr.; lâminas 0,8$2,7 \times 0,15-0,25 \mathrm{~cm}$, lineares, ápice obtuso, base reta, simétrica, face adaxial glabra, face abaxial glabra e às vezes escabra na nervura central, margens escabras, 6 nervuras secundárias. Inflorescências $3-3,7 \mathrm{~cm}$ compr., com 4 ramos unilaterais espiciformes verticilados, pedúnculos $0,5-1 \mathrm{~cm}$ compr., glabros, ráquis e pedicelos escabros, axilas pubescentes. Espiguetas solitárias, 2-3 mm compr.; gluma inferior 0,9-1,4 mm compr., lanceolada, aguda, escabras na nervura central, margens glabras, 1-nervada; gluma superior 1,8-2 mm compr., lanceolada, apiculada, escabras na nervura central, margens glabras, 1nervada; lema inferior com flor bissexuada, 2-2,6 $\mathrm{mm}$ compr., arista 6-14 mm compr., lanceolado, agudo, escabro na região apical, margens escabras, 3nervada; pálea inferior ca. $2 \mathrm{~mm}$ compr., lanceolada, aguda, escabra, margens escabras, 3-nervada; lema superior neutro, $0,2 \mathrm{~mm}$ compr., arista ca. $3 \mathrm{~mm}$ compr., filiforme, agudo, escabro, margens ciliadas; pálea superior ausente. Frutos não analisados.

Material selecionado: trilha da pousada, 27.V.2007, fl., A.C. Mota et al. 67 (CEPEC).

Diferencia-se de Chloris orthonoton pelos caracteres comentados na discussão da espécie anterior.

No Brasil distribui-se nas Regiões CentroOeste, Sudeste e Sul, em campos secos, campos úmidos e campos arenosos do litoral e, mais raramente, em cerrado (Longhi-Wagner 2001b). $\mathrm{Na}$ área de estudos, indivíduos da espécie ocorrem em locais alterados no entorno da floresta, sob alta luminosidade. Foi coletada fértil no mês de maio.

\section{Eleusine Gaertn., Fruct. Sem. Pl. 1: 7. 1788.}

Eleusine inclui sete a nove espécies de regiões tropicais do globo, geralmente associadas a locais alterados (Boechat et al. 2001a). Caracterizase pelas inflorescências racemosas, com ramos unilaterais espiciformes digitados, verticilados ou conjugados no ápice do colmo florífero, espiguetas com numerosos antécios, geralmente sem antécios apicais rudimentares, com lemas múticos.

Renvoize (1984) citou apenas uma espécie deste gênero para a Bahia, a qual foi registrada para $\mathrm{a}$ área de estudos.
2.1 Eleusine indica (L.) Gaertn., Fruct. Sem. Pl. 1: 8. 1788.

Fig. 1d-f

Plantas perenes, cespitosas, $10-20 \mathrm{~cm}$ alt., entrenós e nós glabros. Folhas com bainhas glabras, margens ciliadas na região apical; lígula membranoso-ciliada, ca. 4 mm compr.; lâminas $3,1-12,3 \times 0,15-0,25 \mathrm{~cm}$, lineares, ápice obtuso, base reta, simétrica, face adaxial com longos tricomas muito esparsos, face abaxial glabra, margens escabras e ciliadas próximo a base, 4 6 nervuras secundárias. Inflorescências 1,5$5,4 \mathrm{~cm}$ compr., com 2-4 ramos unilaterais espiciformes digitados a subdigitados, pedúnculos $0,5-5 \mathrm{~cm}$ compr., glabros; ráquis e pedicelos glabros a escabros, axilas glabras. Espiguetas solitárias, 2,9-3,8 mm compr.; gluma inferior 1,1-1,2 mm compr., oval, obtusa, escabra na nervura central, margens glabras, 1-nervada; gluma superior 1,8-2 mm compr., oval, obtusa, escabra na nervura central, margens glabras, $7-$ nervada; 3-4 lemas com flor bissexuada, 1,2$2 \mathrm{~mm}$ compr., múticos, ovais, obtusos, escabros na nervura central, margens glabras, 5-7nervados; páleas 1-1,9 mm compr., ovais, obtusas, escabras nas quilhas, margens glabras, 2-nervadas. Frutos não analisados.

Material selecionado: trilha para a torre, 28.II.2008, fl., A.C. Mota 235 (HUEFS).

Eleusine indica diferencia-se das demais espécies da área de estudos por apresentar espiguetas com número elevado de antécios, sem antécio apical rudimentar, e lemas não aristados.

De origem asiática, foi introduzida no Brasil, onde ocorre em locais alterados (Boechat et al. 2001a). Na região de estudos, foi encontrada em locais alterados no entorno da floresta, sob alta luminosidade. Foi coletada fértil no mês de fevereiro.

\section{Sporobolus R. Br., Prodr.: 169. 1810.}

Sporobolus inclui ca. 150 espécies ocorrentes em regiões tropicais, subtropicais e temperadas de ambos os hemisférios (Renvoize 1984). Apresenta inflorescências paniculadas, laxas a contraídas, ramos alternos, verticilados ou subverticilados, espiguetas solitárias, com apenas um antécio, e lemas não aristados.

No Brasil, ocorrem 27 espécies, com centro de diversidade no Brasil Central (Boechat et al. 2001b). Renvoize (1984) citou cinco espécies para a Bahia, sendo registrada apenas uma para a área de estudos. 


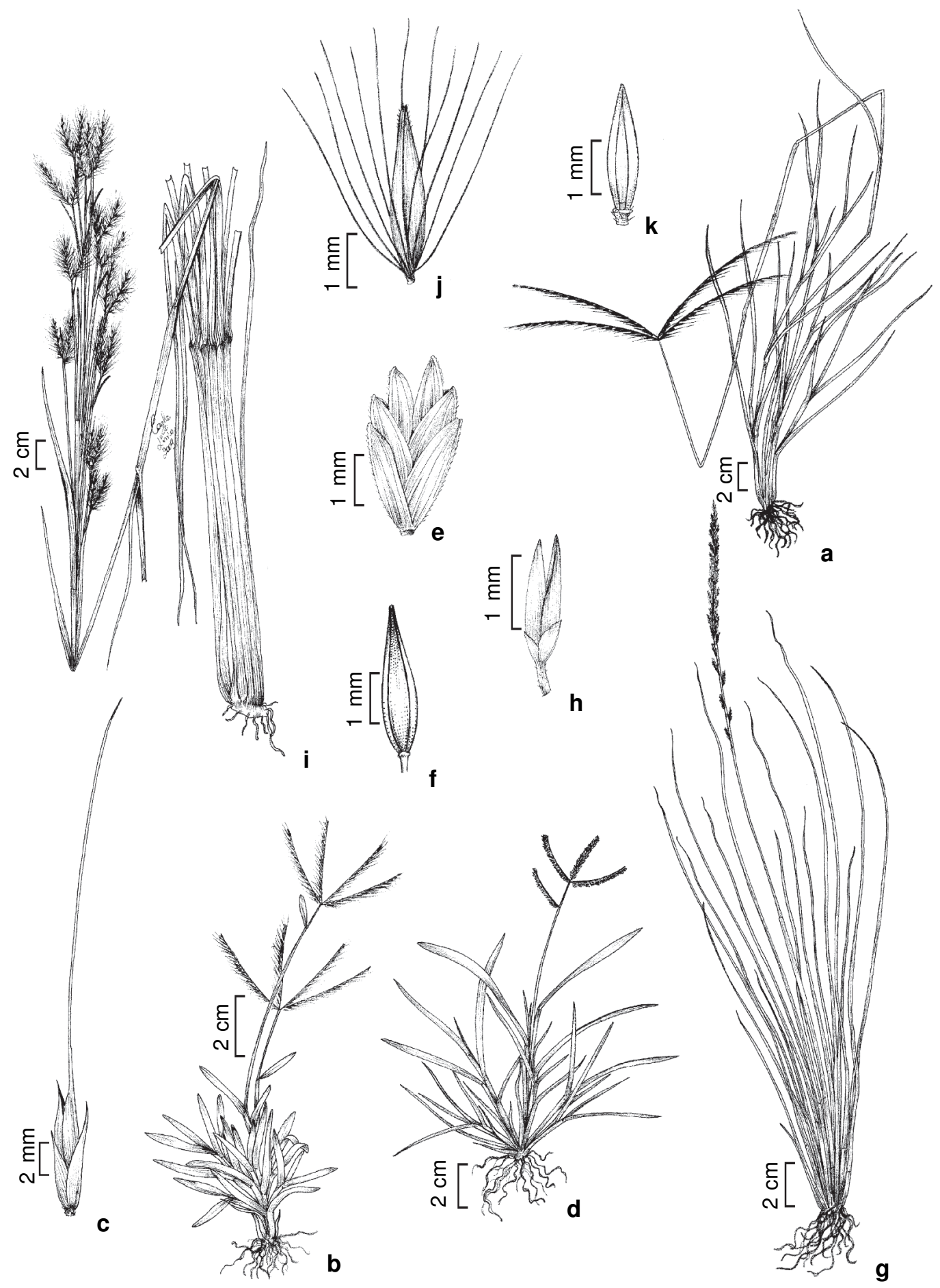

Figura 1 - a. Chloris orthonoton - hábito (A.C. Mota 181 (HUEFS)). b-c. Chloris pycnothrix-b. hábito; c. espigueta (A.C. Mota et al. 67 (CEPEC)). d-f. Eleusine indica-d. hábito; e. espigueta; f. antécio, vista da pálea (A.C. Mota 235 (HUEFS)). g-h. Sporobolus indicus - g. hábito; h. espigueta (A.C. Mota 182(HUEFS)). i-k. Andropogon bicornis - i. hábito; j. espigueta; k. antécio superior, vista da pálea (A.C. Mota 179 (HUEFS)).

Figure 1 - a. Chloris orthonoton - habit (A.C. Mota 181 (HUEFS)). b-c. Chloris pycnothrix - b. habit c. spikelet (A.C. Mota et al. 67(CEPEC)). d-f. Eleusine indica-d. habit; e. spikelet; f. anthecium, palea view (A.C. Mota 235 (HUEFS)). g-h. Sporobolus indicus-g. habit; h. spikelet (A.C. Mota 182 (HUEFS)). i-k. Andropogon bicornis - i. habit, j. spikelet; k. upper anthecium, palea view (A.C. Mota 179(HUEFS)). 
3.1 Sporobolusindicus (L.) R. BR., Prodr.: 170.1810.

Fig. 1g-h

Plantas perenes, cespitosas, $30-65 \mathrm{~cm}$ alt., entrenós e nós glabros. Folhas com bainhas glabras, margens ciliadas; lígula membranoso-ciliada, ca. $0,2 \mathrm{~mm}$ compr.; lâminas 25-43×0,1-0,2 cm, lineares, ápice agudo, base reta, simétrica, face adaxial escabra, face abaxial glabra, margens ciliadas na base, 4 nervuras secundárias. Inflorescências 9-17 cm compr., paniculadas, contraídas, congestas, pedúnculos 14,5 cm compr., glabros; ráquis, ramos e pedicelos glabros a escabros, axilas glabras. Espiguetas solitárias, 1,4-1,8 mm compr.; gluma inferior $0,2-$ $0,3 \mathrm{~mm}$ compr., oval, obtusa, glabra, margens glabras, enérvea; gluma superior $0,3-0,5 \mathrm{~mm}$ compr., oval, obtusa, escabra, margens glabras, 1-nervada; lema 1,2-1,4 mm compr., lanceolado, agudo, escabro, margens glabras, 1-3-nervado; pálea 1-1,5 mm compr., lanceolada, obtusa, escabra, margens glabras, 2-nervada. Frutos não analisados.

Material selecionado : trilha da torre, 25.I.2008, fl., A.C. Mota 207 (HUEFS).

Sporobolus indicus diferencia-se das demais espécies encontradas na área de estudos por apresentar inflorescências paniculadas, contraídas e congestas, com espiguetas solitárias, com um só antécio e múticas.

Amplamente distribuída no Brasil, em locais alterados (Boechat \& Longhi-Wagner 1995). Na área de estudos, as touceiras desta espécie foram encontradas em áreas alteradas no entorno da floresta, sob alta luminosidade, e foi observada em floração no mês de janeiro.

\section{Panicoideae}

Panicoideae é a maior subfamília de Poaceae, incluindo ca. 220 gêneros e aproximadamente 3.300 espécies (Sánchez-Ken \& Clark 2010). Atualmente inclui Centotecoideae em sua delimitação e está dividida em doze tribos (Sánchez-Ken \& Clark 2010). A maioria dos seus representantes está distribuída nas duas maiores tribos, Paniceae (ca. 10 gêneros e 2.000 espécies) e Andropogoneae (ca. 87 gêneros e 1.060 espécies) (Sánchez-Ken \& Clark 2010).

Seus representantes apresentam lâminas foliares sésseis, às vezes com um leve estreitamento em direção à base (pseudopecíolo). As espiguetas possuem um lema estéril e uma flor bissexuada, ou (1-)2 a muitas flores bissexuadas, com redução tanto acima quanto abaixo das flores férteis, normalmente desarticulando-se abaixo das glumas, ou acima delas, em Arundinelleae e Tristachyideae.

$\mathrm{Na}$ área de estudos foram registrados 15 gêneros e 31 espécies, dos quais 14 gêneros e 30 espécies pertencentes a Paniceae, e um único gênero com uma espécie, a Andropogoneae.

\section{Chave para os gêneros de Panicoideae}

1. Inflorescências com ramos floríferos subtendidos por espatéolas 1. Andropogon

1'. Inflorescências com ramos floríferos não subtendidos por espatéolas.

2. Espiguetas rodeadas, na base, por cerdas livres ou concrescidas em algum grau.

3. Cerdas persistentes na ráquis após a queda das espiguetas maduras, livres entre si, geralmente apenas uma cerda por espigueta 13. Setaria

3'. Cerdas decíduas com as espiguetas maduras, concrescidas em diferentes graus, muitas cerdas por conjunto de espiguetas 11. Pennisetum

2'. Espiguetas nuas, não rodeadas por cerdas.

4. Antécio superior com duas alas ou cicatrizes na base do lema

5. Ichnanthus

4'. Antécio superior sem alas ou cicatrizes na base do lema.

5. Plantas de hábito bambusóide; espiguetas oblíquas nos pedicelos, glumas e lema inferior tornando-se purpúreos até negros, na maturação, tomentosos no ápice ........ 6.Lasiacis

5'. Plantas nunca de hábito bambusóide; espiguetas eretas nos pedicelos; glumas e lema inferior não purpúreos a negros, na maturação, às vezes com tricomas curtos e esparsos.

6. Inflorescências racemosas.

7. Espiguetas com a gluma superior coberta por tricomas uncinados, na maturação (tricomas híspidos na espigueta imatura) 12. Pseudechinolaena

7'. Espiguetas com a gluma superior não provida de tricomas uncinados ou híspidos. 
8. Antécio superior transversalmente rugoso 15. Urochloa

8. Antécio superior liso, estriado ou papiloso, nunca transversalmente rugoso.

9. Gluma e lema superior abaxiais à raquis

9'. Gluma e lema superior adaxiais à raquis.

10. Lema superior cartáceo a cartilaginoso, com margens hialinas e expandidas, cobrindo quase totalmente a pálea

4. Digitaria

10'. Lema superior coriáceo, com margens não hialinas e não expandidas, cobrindo levemente as margens da pálea 10. Paspalum

6'. Inflorescências paniculadas.

11. Panículas com ramos unilaterais.

12. Espiguetas com lema inferior 5-nervado

7. Ocellochloa

12'. Espiguetas com lema inferior 3-nervado 8. Panicum

11'. Panículas sem ramos unilaterais.

13. Espiguetas com antécio superior apiculado.

14. Espiguetas com gluma inferior 1 ou 7 nervada. 3. Dichanthelium

14'. Espiguetas com gluma inferior 3-nervada 9. Parodiophyllochloa

13'. Espiguetas com antécio superior não apiculado.

15. Espiguetas com gluma superior 3-nervada; pálea inferior conspicuamente expandida na maturação, sobressaindo do lema 14. Steinchisma

15'. Espiguetas com gluma superior 5-nervada; pálea inferior não expandida na maturação, não sobressaindo do lema 8. Panicum

1. Andropogon L., Sp. Pl. 2: 1045. 1753.

Andropogon inclui ca. 100 espécies predominantemente tropicais (Zanin \& LonghiWagner 2006). Apresenta inflorescências geralmente com dois ou mais ramos floríferos por espatéola, ramos conjugados ou digitados, espatéolas às vezes pouco evidentes, menos frequentemente inflorescências racemosas, corimbiformes ou alongadas, com muitas espatéolas; espiguetas pareadas, sendo uma séssil e uma pedicelada.

Renvoize (1984) citou nove espécies desse gênero para a Bahia, o qual está representado apenas por uma única espécie na área de estudos.

\subsection{Andropogon bicornis L., Sp. Pl. 2: 1046. 1753.}

Fig. 1i-k

Plantas perenes, cespitosas, ca. $95 \mathrm{~cm}$ alt., entrenós e nós glabros. Folhas com bainhas glabras, margens glabras; lígula membranoso-ciliada, ca. 0,7 mm compr.; lâminas 13,9-45,7 ×0,2-0,3 cm, lineares, ápice agudo, base reta, simétrica, face adaxial pubescente a hirsuta na base, face abaxial glabra, margens escabras e às vezes ciliadas na base, nervuras secundárias não muito diferenciadas. Inflorescências $25-37 \times 7-8 \mathrm{~cm}$, formada por vários pares de ramos floríferos conjugados, cada par envolvido por espatéola; espatéolas lineares, agudas, escabras na região apical, 3,1-4,9 cm compr.; ramos 2,2-3 cm compr., ramos e pedicelos densamente pilosos. Espiguetas pareadas, a séssil com flor bissexuada e a pedicelada neutra. Espiguetas sésseis 3-3,1×0,4 mm; gluma inferior 3-3,1 mm compr., lanceolada, aguda, escabra na nervura central, margens glabras, 2-nervada; gluma superior ca. 2,5 mm compr., lanceolada, aguda, escabra na nervura central, margens glabras, 1nervada; lema inferior neutro, ca. 1,8 mm compr., lanceolado, agudo, glabro, margens glabras, 1nervado; pálea inferior ausente; lema superior com flor bissexuada, ca. 1,8 mm compr, lanceolado, agudo, 1-nervado, glabro, margens glabras; pálea superior ca. 0,8 mm compr., oval, obtusa, glabra, margens glabras. Espiguetas pediceladas, reduzidas. Frutos não analisados.

Material selecionado: trilha da torre, 24.XI.2007, fl., A.C. Mota 179 (HUEFS).

Andorpogon bicornis pode ser diferenciada das demais espécies de Panicoideae da área de estudos pelas inflorescências subtendidas por espatéolas, além da densa pilosidade creme das inflorescências, que assumem aspecto plumoso. É comum apresentarem espiguetas pediceladas estaminadas e de tamanho semelhante às sésseis (Zanin 2001), porém isto não foi observado no material da Serra Bonita.

É amplamente distribuída no Brasil, ocorrendo em áreas de cerrado, campos e locais alterados (Zanin 2001). Na região de estudos, formam 
touceiras em locais alterados no entorno da floresta, sob alta intensidade luminosa. Foi coletada fértil nos meses de junho e novembro.

\section{Axonopus P. Beauv., Ess. Agrostogr. 12: 154. 1812.}

Axonopus compreende ca. 100 espécies, a maioria da América tropical e subtropical e apenas uma da África, ocorrendo em campos, savanas, clareiras de florestas e locais alterados (Valls et al. 2001). Caracteriza-se por apresentar inflorescências racemosas com (1)2-muitos ramos unilaterais espiciformes conjugados, subdigitados, subverticilados ou alternos, com espiguetas solitárias, gluma e pálea inferiores ausentes e com gluma e lema superiores abaxiais à ráquis.

Renvoize (1984) citou 16 espécies para a Bahia, e na área de estudos, está representado por uma única espécie.

\subsection{Axonopus fissifolius (Raddi) Kuhlm., Comm.} Lin. Telegr., Bot. 67(11): 87. $1922 . \quad$ Fig. 2a-c

Plantas perenes, estoloníferas, às vezes cespitosas e emitindo estolhos finos, $20-30 \mathrm{~cm}$ alt., entrenós e nós glabros. Folhas com bainhas glabras, margens glabras; lígula membranoso-ciliada, ca. $0,2 \mathrm{~mm}$ compr.; lâminas 3,7-13,1 ×0,2-0,4 cm, oblongo-lanceoladas, ápice obtuso, base reta, simétrica, glabra em ambas as faces, margens escabras, 4-8 nervuras secundárias. Inflorescências 4,5-6,1 cm compr., com 2 ramos unilaterais espiciformes conjugados, parcialmente inclusas ou pedunculadas, pedúnculos $3-7,5 \mathrm{~cm}$ compr., glabros; ráquis, ramos, axilas e pedicelos escabros. Espiguetas solitárias, 1,5-1,6 ×0,2-0,3 mm, oblongoelípticas, agudas, dorsalmente comprimidas; gluma inferior ausente; gluma superior 1,2-1,4 mm compr., elíptica, aguda, pilosa nas nervuras, margens glabras, 2-nervada; lema inferior neutro, 1,2-1,5 mm compr., elíptico, agudo, piloso nas nervuras, margens glabras, 2-nervada; pálea inferior ausente; antécio superior 1-1,3 mm compr., oblongo-elíptico, agudo, piloso no ápice do lema superior, longitudinalmente papiloso, estramíneo. Frutos não analisados.

Material selecionado: trilha da torre, 24.XI.2007, fl., A.C. Mota 180 (HUEFS).

Axonopus fissifolius pode ser confundida com algumas espécies de Paspalum L. ou Digitaria Haller ocorrentes na área de estudos, que também apresentam inflorescências com dois racemos conjugados, a exemplo de Digitaria violascens Link, Paspalum conjugatum P.J. Bergius e P. pumilum Nees. Porém, A. fissifolius pode ser diferenciada pelo ápice da lâmina foliar obtuso e gluma e lema inferior abaxiais à ráquis, enquanto as outras espécies apresentam ápice da lâmina foliar agudo e gluma e lema inferior adaxiais à ráquis.

Dedecca (1956) citou a ocorrência de Axonopus fissifolius para Minas Gerais, São Paulo, Rio de Janeiro, Mato Grosso e Rio Grande do Sul. Renvoize (1984) registrou a ocorrência desta espécie também para a Bahia. Na área de estudos, ocorre em ambientes alterados no entorno da floresta, sob alta intensidade luminosa e foi coletada florida apenas no mês de novembro.

3. Dichanthelium (Hitchc. \& Chase) Gould, Brittonia 26(1): 59. 1974.

Dichanthelium inclui ca. 55 espécies, de lugares úmidos e sombreados da América do Norte, ocorrendo também nas Américas Central e Sul (Aliscioni et al. 2003). É caracterizado por possuir frequentemente dimorfismo de colmos e lâminas foliares, inflorescências paniculadas, abertas e laxas, raramente contraídas, espiguetas pareadas, com gluma inferior 1-7nervada, gluma superior e lema inferior subiguais, (5)-7-15-nervados, antécio superior endurecido, papiloso e apiculado.

Foram citadas para o Brasil 23 espécies, reconhecidas sob Panicum subg. Dichantelium sect. Dichantelium (Zuloaga et al. 1993), dez das quais ocorrendo na Bahia, e duas na área de estudos.

\section{Chave para as espécies de Dichanthelium}

1 Inflorescências 12,5-18 $\times 10,5-16,5 \mathrm{~cm}$; espiguetas com gluma inferior 0,9-1,3 mm compr., 7-nervada; antécio superior 1,5-1,7 mm compr., negro na maturação .............................................. 3.1 D. hebotes

1'. Inflorescências $4-8 \times 3,5-8 \mathrm{~cm}$; espiguetas com gluma inferior ca. $0,5 \mathrm{~mm}$ compr., 1 -nervada; antécio superior ca. 1 mm compr., estramíneo na maturação . 3.2 D. sciurotoides 


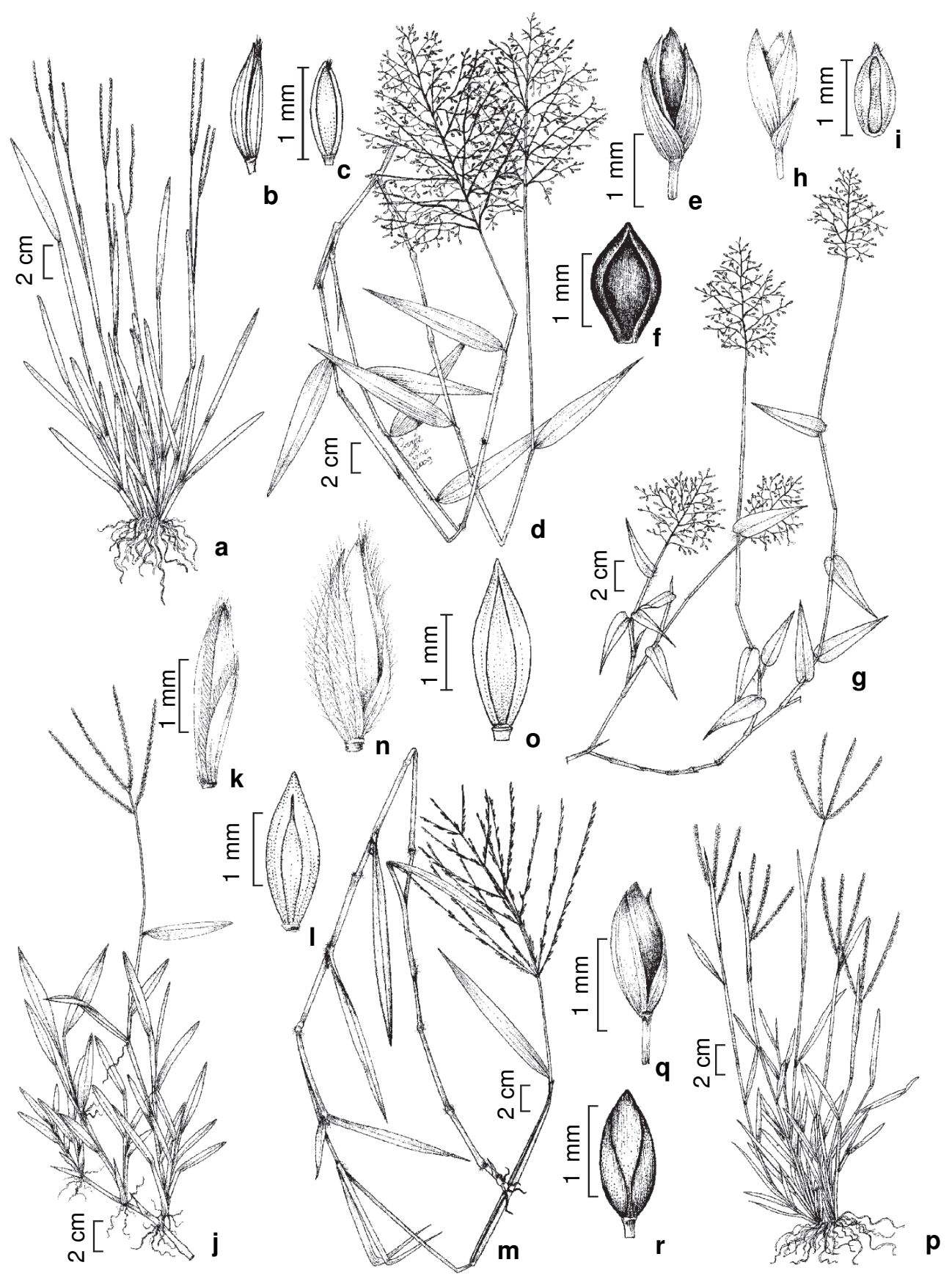

Figura 2 - a-c. Axonopus fissifolius - a. hábito; b. espigueta; c. antécio superior, vista da pálea (A.C. Mota 180 (HUEFS )). d-f. Dichanthelium hebotes - d. hábito; e. espigueta; f. antécio superior, vista da pálea(A.C. Mota 191(HUEFS)). g-i. Dichanthelium sciurotoides - g. hábito; h. espigueta; i. antécio superior, vista da pálea (gA.C. Mota 245 (HUEFS), h-i A.C. Mota 73 (HUEFS)). j-1. Digitaria ciliaris - j. hábito; k. espigueta; 1. antécio superior, vista da pálea (A.C. Mota 219(HUEFS)). m-o. Digitaria doellii - m. hábito; n. espigueta; o. antécio superior, vista da pálea (A.C. Mota 193 (HUEFS)). p-r. Digitaria violascens - p. hábito; q. espigueta; r. antécio superior, vista da pálea (p A.C. Mota 237(HUEFS), q-r A.C. Mota 236(HUEFS)).

Figure 2 - a-c. Axonopus fissifolius - a. habit; b. spikelet; c. anthecium, palea view (A.C. Mota 180 (HUEFS)). d-f. Dichanthelium hebotes d. habit; e. spikelet; f. anthecium, palea view (A.C. Mota 191 (HUEFS)). g-i.Dichanthelium sciurotoides - g. habit; h. spikelet; i. anthecium, palea view (g A.C. Mota 245 (HUEFS); h-i A.C. Mota 73 (HUEFS)). j-1. Digitaria ciliaris - j. habit; k. spikelet; 1. anthecium, palea view (A.C. Mota 219 (HUEFS)). m-o. Digitaria doellii - m. habit; n. spikelet; o. anthecium, palea view (A.C. Mota 193 (HUEFS)). p-r. Digitaria violascens p. habit; q. spikelet; r. anthecium, palea view (p A.C. Mota 237 (HUEFS); q-r A.C. Mota 236(HUEFS)). 
3.1 Dichanthelium hebotes (Trin.) Zuloaga, Amer. J. Bot. 90: 816. 2003.

Fig. 2d-f

Plantas perenes, decumbentes, radicantes nos nós inferiores, $80-110 \mathrm{~cm}$ alt., entrenós e nós pilosos. Folhas com bainhas pilosas, margens ciliadas; lígula membranoso-ciliada, ca. $0,5 \mathrm{~mm}$ compr.; lâminas 6,5-13 ×0,9-1,8 cm, lanceoladas, ápice acuminado, base arredondada, simétrica, pilosas em ambas as faces, margens escabras, 10 nervuras secundárias. Inflorescências 12,5-18 $\times$ $10,5-16,5 \mathrm{~cm}$, paniculadas, com ramos primários, secundários e terciários, pedúnculos 4,5-18 cm compr., pilosos, ráquis, ramos e pedicelos pilosos. Espiguetas pareadas, 1,6-1,8 $\times 0,5 \mathrm{~mm}$, obovais, apiculadas; gluma inferior 0,9-1,3 mm compr., oval, obtusa, escabra, margens glabras, 7-nervada; gluma superior 1,6-1,8 mm compr., oval, obtusa, escabra, margens glabras, 9-nervada; lema inferior neutro, ca. 1,8 mm compr., oval, agudo, escabro no ápice, margens glabras, 9-nervado; pálea inferior ca. $0,1 \mathrm{~mm}$ compr., glabra, enérvea; antécio superior 1,5-1,7 mm compr., elíptico, apiculado, glabro, papiloso longitudinalmente, negro na maturação. Frutos não analisados.

Material selecionado: trilha da pousada, 24.XI.2007, fl., A.C. Mota 191 (HUEFS).

Dichanthelium hebotes pode ser facilmente diferenciada de D. sciurotoides (Zuloaga \& Morrone) Davidse pelas inflorescências maiores. As espiguetas também são bastante distintas, tanto pelo comprimento das glumas e antécios, quanto pela cor do antécio na maturação, que em $D$. hebotes é negro $v s$. estramíneo em $D$. sciurotoides.

Zuloaga et al. (1993) citaram a espécie para o Ceará e Regiões Sudeste e Sul do Brasil. Ocorrendo geralmente em locais sombreados, bordas e interior de floresta, também em restingas e campos rupestres (Zuloaga et al. 2001a). O presente trabalho registra pela primeira vez a ocorrência da espécie para a Bahia. $\mathrm{Na}$ área de estudos, foi observada fértil apenas no mês de novembro. Ocorre sob a sombra da borda da floresta, com baixa intensidade luminosa.

3.2 Dichanthelium sciurotoides (Zuloaga \& Morrone) Davidse, Novon 2(2): 104. 1992.

Fig. 2g-i

Plantas anuais, decumbentes, radicantes nos nós inferiores, $30-80 \mathrm{~cm}$ alt., entrenós glabros, nós pilosos. Folhas com bainhas pilosas na base, margens ciliadas; lígula membranoso-ciliada, ca. $0,2 \mathrm{~mm}$ compr.; lâminas 1,6-10 ×0,9-1,9 cm, lanceoladas, ápice acuminado, base subcordada, levemente assimétrica, face adaxial pubescente a pilosa, face abaxial pubescente a pilosa, margens curtoescabras, ciliadas, 8 nervuras secundárias. Inflorescências 4-8 ×3,5-8 cm, paniculadas, com ramos primários e secundários, pedúnculos $3-$ $25 \mathrm{~cm}$ compr., esparso-pilosos, ráquis, ramos e pedicelos glabros a pilosos. Espiguetas pareadas, ca. 1,5 $\times 0,8 \mathrm{~mm}$, lanceoladas, apiculadas; gluma inferior ca. $0,5 \mathrm{~mm}$ compr., triangular, aguda, curtoescabra, margens glabras, 1-nervada; gluma superior ca. 1,5 mm compr., lanceolada, aguda, curto-escabra, margens glabras, 7-nervada; lema inferior neutro, ca. $1,5 \mathrm{~mm}$ compr., lanceolado, agudo, curto-escabro, margens glabras, 7nervado; pálea inferior ca. $0,1 \mathrm{~mm}$ compr., glabra, enérvea; antécio superior ca. $1 \mathrm{~mm}$ compr., oval, apiculado, glabro, papiloso longitudinalmente, estramíneo na maturação. Frutos não analisados. Material selecionado: trilha da pousada para o Centro de Pesquisas, 30.VI.2007, fl., A.C. Mota 73 (HUEFS); trilha da pousada, 25.VIII.2007, fl., F. M. Ferreira et al. 1309 (CEPEC).

Essa espécie difere de Dichanthelium hebotes pelos caracteres citados na discussão da espécie anterior.

Ocorre nas Regiões Nordeste, Sudeste e Sul (até Santa Catarina) do Brasil, em locais sombreados de interior de floresta, em campos de altitude e em campos baixos e arenosos do litoral (Zuloaga et al. 2001a). Na área de estudos, foi observada florida durante todo o ano. As touceiras de D. sciurotoides ocorrem sob sombra nas bordas da floresta.

4. Digitaria Haller, Hist. Stirp. Helv. 2: 244. 1768.

Digitaria inclui ca. 300 espécies, distribuídas nas regiões tropicais e subtropicais do globo (Canto-Dorow 2001a). Caracteriza-se pelas inflorescências racemosas, com 1-muitos ramos unilaterais espiciformes alternos, verticilados, conjugados a digitados. As espiguetas são pareadas ou agrupadas em três a seis por nó, com ou sem gluma inferior, sendo a gluma e o lema superior adaxiais à raquis, este último apresentando margens caracteristicamente expandidas e hialinas, cobrindo cerca de metade da pálea.

Para o Brasil foram citadas 36 espécies (CantoDorow 2001b), nove das quais referidas para a Bahia (Renvoize 1984), e na área de estudos, está representado por três espécies. 


\section{Chave para as espécies de Digitaria}

1. Inflorescências com 17-31 ramos unilaterais espiciformes, alternos a verticilados ao longo da ráquis; lâminas foliares com 10-16 nervuras secundárias ..... 4.2 D. doellii

1'. Inflorescências com 2-6 ramos unilaterais espiciformes, digitados a subdigitados; lâminas foliares com 6-8 nervuras secundárias.

2. Espiguetas pareadas, 2,8-2,9 mm compr., com gluma inferior reduzida, antécio superior curtoapiculado, castanho-claro na maturação ... 4.1 D. ciliaris

2'. Espiguetas em grupos de 3-4, 1,1-1,2 mm compr., gluma inferior ausente, antécio superior agudo, castanho-escuro na maturação 4.3 D. violascens

4.1 Digitaria ciliaris (Retz.) Koeler, Descr. Gram.: 27. 1802. Fig. 2j-1

Plantas anuais, decumbentes, radicantes nos nós inferiores, 40-50 cm alt., entrenós glabros, nós pubescentes, pilosos a hirsutos. Folhas com bainhas escabras ou hirsutas, margens glabras; lígula membranosa, 2-3 mm compr.; lâminas 3-9,5 ×0,4$0,7 \mathrm{~cm}$, lineares a linear-elípticas, ápice agudo, base reta a arredondada, simétrica, face adaxial escabra e com tricomas longos esparsos ou concentrados na base, face abaxial escabra e com tricomas longos esparsos, margens escabras, 6-8-nervuras secundárias. Inflorescências 6,5-10 cm compr., com 4 ramos unilaterais espiciformes digitados, pedúnculos 7-15 cm compr., glabros, ráquis, ramos e pedicelos escabros. Espiguetas pareadas, 2,8-2,9 $\times 0,6-0,7 \mathrm{~mm}$, lanceoladas, agudas; gluma inferior ca. $0,1 \mathrm{~mm}$ compr., triangular, aguda, glabra, margens glabras, enérvea; gluma superior 1,2-1,8 $\mathrm{mm}$ compr., lanceolada, aguda, denso-pilosa entre as nervuras, margens ciliadas, $3-$ nervada; lema inferior neutro, 2,7-2,8 mm compr., lanceolado, agudo, denso-piloso entre as nervuras, margens ciliadas, 7-nervado; pálea inferior ausente; antécio superior 2,6-2,8 mm compr., lanceolado, curtoapiculado, glabro, longitudinalmente papiloso, castanho-claro na maturação. Frutos não analisados. Material selecionado : trilha da torre, 25.I.2008, fl., A.C. Mota 219 (HUEFS).

Dentre as espécies de Digitaria ocorrentes na área de estudos, $D$. ciliaris pode ser confundida apenas com $D$. violascens Link, por compartilhar o hábito e igual número e comprimento dos ramos da inflorescência. Entretanto, várias diferenças nas espiguetas as separam, como mencionado na chave.

Espécie amplamente distribuída no Brasil, geralmente ocorrendo em locais alterados de campo e cerrado (Canto-Dorow 2001a). Na área de estudos suas touceiras ocorrem sob alta intensidade luminosa no topo da serra e em áreas alteradas no entorno da floresta; foi coletada fértil apenas em janeiro.
4.2 Digitaria doellii Mez, Bot. Jahrb. Syst. 56, Beibl. 125: 8. $1921 . \quad$ Fig. 2m-o

Plantas perenes, estoloníferas, $30-130 \mathrm{~cm}$ alt., entrenós glabros, nós pubescentes, pilosos a hirsutos. Folhas com bainhas pilosas a hirsutas, margens glabras ou ciliadas; lígula membranosa, 3-6 mm compr.; lâminas 6,4-30,5 ×0,5-0,9 cm, linear-lanceoladas, ápice agudo, base arredondada, simétrica, face adaxial com tricomas longos esparsos, face abaxial glabra, margens escabras, 10-16 nervuras secundárias. Inflorescências (5-6) 13,5-20,5 cm compr., com 17-31 ramos unilaterais espiciformes verticilados a alternos ao longo da ráquis, pedúnculos 3,5-27,5 cm compr., glabros; ráquis, ramos e pedicelos escabros. Espiguetas pareadas, 2,5-2,8 $\times 0,6-0,7 \mathrm{~mm}$, elípticas, agudas; gluma inferior 0,2-1 mm compr., triangular, ápice agudo, pilosa na nervura central, margens glabras, hialinas, 0-1nervada; gluma superior 1,8-2 mm compr., elíptica, aguda, pilosa nas nervuras secundárias, margens glabras, 5-nervada; lema inferior neutro, 2,2-2,7 mm compr., elíptico, agudo, piloso nas nervuras secundárias, margens ciliadas, 7-nervado; pálea inferior ausente; antécio superior 2-2,2 mm compr., elíptico, agudo, glabro, longitudinalmente papiloso, castanho-claro. Frutos não analisados.

Material selecionado: trilha da pousada para o Centro de Pesquisas, 24.XI.2007, fl., A.C. Mota 193 (HUEFS).

Digitaria doellii diferencia-se claramente das outras espécies do gênero encontradas na área de estudos especialmente pelas inflorescências com muitos ramos verticilados a alternos ao longo da ráquis, em contraposição às duas outras espécies que apresentam inflorescências com poucos ramos digitados a subdigitados.

Foi referida para o Rio de Janeiro por Mez (1921). Renvoize (1984) e Canto-Dorow (2001b) citaram a coleção E. B. dos Santos \& C. A. Ramos 78 (RB), originária de florestas baixas da região litoral sul da Bahia sob D. doellii, a qual é idêntica ao 
material coletado na área de estudos e nos quais sua identificação foi aqui baseada. As touceiras dessa espécie ocorrem em áreas alteradas no entorno da floresta, sob alta intensidade luminosa. Foi observada em floração apenas nos meses de novembro e março.

\subsection{Digitaria violascens Link, Hort. Berol. 1: 229.} 1827.

Fig. 2p-r

Plantas anuais, decumbentes, radicantes nos nós inferiores, $25-45 \mathrm{~cm}$ alt., entrenós e nós glabros. Folhas com bainhas glabras, margens glabras; lígula membranosa, ca. 1,2 mm compr.; lâminas 3,1-14,8× 0,2-0,5 cm, linear-lanceoladas, ápice agudo, base reta, simétrica, glabra em ambas as faces, margens glabras a escabras, 6-8-nervuras secundárias. Inflorescências (3,3) 4,3-10,3 cm compr., com 2-6 ramos unilaterais espiciformes digitados a subdigitados, inclusas a pedunculadas, pedúnculos 2,4-11,8 cm compr., glabros; ráquis, ramos, axilas e pedicelos escabros. Espiguetas em grupos de 3-4, 1,1-1,2 × 0,4-0,5 mm, elípticas, agudas; gluma inferior ausente; gluma superior 1-1,1 mm compr., elíptica, aguda, pubescente entre as nervuras, margens pubescentes, 3-5-nervada; lema inferior neutro, 1-1,2 mm compr., elípticos, agudos, pubescente entre as nervuras, margens pubescentes, 5-7-nervado; pálea inferior ausente; antécio superior 1-1,2 mm compr., elíptico, agudo, glabro, longitudinalmente papiloso, castanho-escuro na maturação. Frutos não analisados.

Material selecionado: próximo ao grotão, 15.III.2007, fl., R. P. Oliveira et al. 1237 (CEPEC); trilha da torre, 28.II.2008, fl., A.C. Mota 237 (HUEFS).

No Brasil encontra-se amplamente distribuída, principalmente em áreas alteradas (Canto-Dorow 2001a). Na área de estudos foi coletada em ambientes alterados no entorno da floresta, sob alta intensidade luminosa. Foi observada fértil nos meses de fevereiro a março.

5. Ichnanthus P. Beauv., Ess. Agrostogr.: 56. 1812. Ichnanthusinclui 30 espécies, uma pantropical e as demais concentradas nos trópicos e subtrópicos americanos, desde o México até o norte da Argentina, a maioria tipicamente umbrófila (Boechat 2005). Apresentam inflorescências paniculadas, espiguetas pareadas e lema superior com duas alas ou cicatrizes características na base.

No Brasil, está representado por 26 táxons nativos e uma espécie exótica (Boechat 2005). Renvoize (1984) citou 14 espécies para a Bahia, das quais quatro ocorrem na área de estudos.

\section{Chave para as espécies de Ichnanthus}

1. Antécio superior com alas livres na base do lema.

2. Lâminas foliares de base atenuada, simétrica; inflorescências $15-16 \mathrm{~cm}$ compr., com ramos primários e secundários, espiguetas ca. $3 \mathrm{~mm}$ compr., antécio superior ca. 2,8 mm compr., com alas 5-6 (1) $\mathrm{mm}$ compr. 5.1 I. calvescens

2'. Lâminas foliares de base arredondada a subcordada, assimétrica; inflorescências 21,5-30,5 cm compr., com ramos primários, secundários e terciários, espiguetas 4,5-5 mm compr., antécio superior 3,5-3,8 mm compr., com alas $1-2 \mathrm{~mm}$ compr.

1'. Antécio superior com cicatrizes na base do lema. 5.2 I. leiocarpus

3. Inflorescências com ramos primários de 6-17 cm compr., com ramos secundários .... 5.3 I. pallens

3'. Inflorescências com ramos primários de 1,4-5 cm compr., sem ramos secundários ..... 5.4 I. tenuis

5.1 Ichnanthus calvescens (Nees ex Trin.) Döll, Fl. Bras. 2(2): 285. 1877.

Fig. 3a-c

Plantas perenes, cespitosas, ca. $1 \mathrm{~m}$ alt., entrenós esparso-pilosos, nós pilosos a hirsutos. Folhas com bainhas glabras, margens ciliadas; lígula membranoso-ciliada, ca. 1 mm compr.; lâminas 926 ×1-2,1 cm, lanceoladas, ápice longo-acuminado, base atenuada, simétrica, pilosa em ambas as faces, margens escabras, 10-12 nervuras secundárias. Inflorescências $15-16 \times 6 \mathrm{~cm}$, paniculadas abertas, laxas, com ramos primários e secundários, pedúnculos ca. $2 \mathrm{~cm}$ compr., pilosos, ráquis pilosa, ramos glabros, axilas dos ramos pilosas, pedicelos glabros. Espiguetas pareadas, ca. $3 \times 1 \mathrm{~mm}$, lanceoladas, agudas; gluma inferior ca. $2,8 \mathrm{~mm}$ compr., lanceolada, acuminada, escabra, margens ciliadas ou glabras, 3-nervada; gluma superior ca. $3 \mathrm{~mm}$ compr., lanceolada, acuminada, escabra, margens glabras, 5-nervada; lema inferior estaminado, ca. 2,8 mm compr., lanceolado, agudo, escabro no 


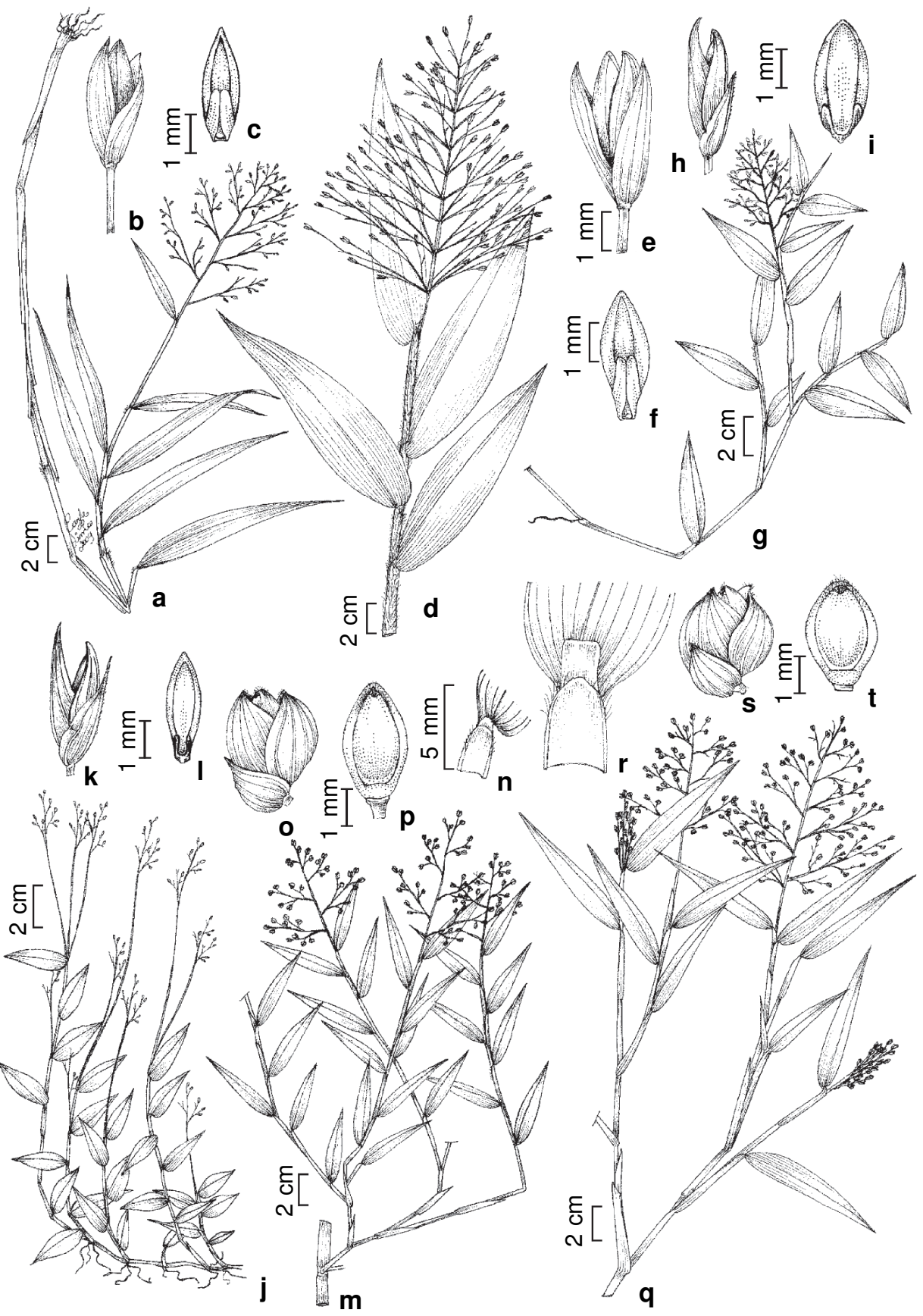

Figura 3 - a-c. Ichnanthus calvescens - a. hábito; b. espigueta; c. antécio superior, vista da pálea (F.M. Ferreira et al. s/n (CEPEC 117619)).d-f. Ichnanthus leiocarpus - d. hábito; e. espigueta; f. antécio superior, vista da pálea. g-i. Ichnanthus pallens-g. hábito; h. espigueta; i. antécio superior, vista da pálea (A.C. Mota 209 (HUEFS)). j-1. Ichnanthus tenuis -j. hábito; k. espigueta; 1. antécio superior, vista da pálea (A.C. Mota 255 (HUEFS)). m-p. Lasiacis divaricata - m. hábito; n. detalhe da lígula; o. espigueta; p. antécio superior, vista da pálea (m-n A.C. Mota 241 (HUEFS); o-p A.C. Mota 251 (HUEFS)). q-t. Lasiacis ligulata-q. hábito; r. detalhe da lígula; s. espigueta; t. antécio superior, vista da pálea (q-r A. M. Amorim et al. 6956 (CEPEC); s-t A.C. Mota 205(HUEFS)).

Figure 3 - a-c. Ichnanthus calvescens - a. habit; b. spikelet; c. anthecium, palea view (F.M. Ferreira et al. s/ $n$ (CEPEC 117619)). d-f. Ichnanthus leiocarpus - d. habit; e. spikelet; f. anthecium, palea view. g-i. Ichnanthus pallens - g. habit; h. spikelet; i. anthecium, palea view (A.C. Mota 209 (HUEFS)). j-1. Ichnanthus tenuis - j. habit; k. spikelet; 1. anthecium, palea view (A.C. Mota 255 (HUEFS)). m-p. Lasiacis divaricata - m. habit; n. detail of the ligule; o. spikelet; p. anthecium, palea view (m-n A.C. Mota 241 (HUEFS); o-p A.C. Mota 251 (HUEFS)). q-t. Lasiacis ligulata q. habit; r. detail of the ligule; s. spikelet; t. anthecium, palea view (q-r A. M. Amorim et al. 6956 (CEPEC); s-t A.C. Mota 205 (HUEFS)). 
ápice, margens glabras, 5-nervado; pálea inferior ca. $2 \mathrm{~mm}$ compr., oblonga, obtusa, escabra nas nervuras, margens glabras, 2-nervada; antécio superior ca. 2,8 mm compr., lanceolado, agudo, glabro, liso, castanho-claro, com duas alas livres na base do lema, 0,5-0,6 (1) mm compr. Frutos não analisados. Material selecionado: trilha da pousada, 25.VIII.2007, fl., F.M. Ferreira et al. s/n (CEPEC 117619).

Ichnanthus calvescens pode ser diferenciada das demais espécies do gênero que ocorrem na área de estudos especialmente pelas lâminas foliares de base atenuada e simétrica em contraste com as bases arredondadas, subcordadas ou cordadas e assimétricas.

Ocorre nas Regiões Norte, Nordeste, Centrooeste e Sudeste do Brasil, em florestas de galeria e de restinga, campo seco a inundável, campos rupestres, menos freqüentemente na caatinga (Boechat 2005). $\mathrm{Na}$ área de estudos, I. calvescens ocorre nas bordas da floresta, com baixa intensidade luminosa, e foi coletada fértil apenas no mês de agosto.

5.2 Ichnanthus leiocarpus (Spreng.) Kunth, Revis. Gramin. 2: 507. 1831.

Fig. 3d-f

Plantas perenes, decumbentes, radicantes nos nós inferiores, ca. $1 \mathrm{~m}$ alt., entrenós pilosos, nós pilosos a lanuginosos. Folhas com bainhas lanuginosas, margens ciliadas; lígula membranosociliada, 2-4 mm compr.; lâminas $(5,5) 9-17 \times 1,2-$ $3,6 \mathrm{~cm}$, elíptico-lanceoladas a lanceoladas, ápice acuminado, base arredondada a subcordada, assimétrica, face adaxial escabra, face abaxial pubescente e pilosa a lanuginosa na base, margens escabras, 12-18 nervuras secundárias. Inflorescências $21,5-30,5 \times 15-23,5 \mathrm{~cm}$, paniculadas, abertas a contraídas, laxas, com ramos primários, secundários e terciários, pedúnculos $1-3 \mathrm{~cm}$ compr., pilosos, ráquis escabra, ramos escabros, axilas dos ramos pilosas, pedicelos escabros. Espiguetas pareadas, 4,5$5 \times 1,5-2 \mathrm{~mm}$, lanceoladas, obtusas; gluma inferior 3,5-5,5 mm compr., lanceolada, aristulada, escabra no ápice, margens glabras, 3-nervada; gluma superior 3,8-4 mm compr., lanceolada, aguda, escabra no ápice, margens glabras, 5-nervada; lema inferior neutro, ca. $3,8 \mathrm{~mm}$ compr., lanceolado, agudo, escabro no ápice, margens glabras, 5-nervado; pálea inferior 3-3,5 mm compr., lanceolada, aguda, glabra, escabra nas nervuras, margens glabras, 2-nervada; antécio superior 3,5-3,8 mm compr., lanceolado, agudo, glabro, liso, castanho-claro a castanho-escuro, com duas alas livres na base do lema, 1-2 mm compr. Frutos não analisados.
Material selecionado: trilha da torre, 24.XI.2007, fl., A.C. Mota 175 (HUEFS).

Ichnanthus leiocarpus pode ser diferenciada das demais espécies do gênero ocorrentes na área de estudos, principalmente pelas inflorescências paniculadas bastante ramificadas, espiguetas maiores e alas livres longas na base do lema superior.

No Brasil, foi registrada para as Regiões Sudeste e Sul, Ceará e Bahia, no interior e bordas de florestas secundárias, higrófilas, caatinga arbórea, sobre solo com afloramento de rochas, e em encostas (Boechat 2005). Na área de estudos, foi encontrada no interior da floresta, sob baixa luminosidade. Foi observada fértil de junho a janeiro.

5.3 Ichnanthus pallens (Sw.) Munro ex Benth, Fl. Hongk.: 414. $1861 . \quad$ Fig. 3g-i

Plantas perenes, decumbentes, radicantes nos nós inferiores, $40-85 \mathrm{~cm}$ alt., entrenós glabros, escabros, pubescentes ou pilosos, nós glabros, pubescentes, pilosos ou hirsutos. Folhas com bainhas glabras, pubescentes, pilosas ou hirsutas, margens ciliadas; lígula membranoso-ciliada, 1-2 mm compr.; lâminas 3,5-10,8 × 0,6-2,5 cm, ovallanceoladas a lanceoladas, ápice acuminado, base arredondada a cordada, assimétrica, face adaxial glabra, escabra, pilosa a hirsuta, face abaxial glabra, escabra, pubescente, pilosa ou hirsuta, margens escabras, 6-10(12) nervuras secundárias. Inflorescências 6-17 × 1,8-8,5 cm, paniculadas, abertas, congestas, com ramos primários e secundários, pedúnculos 1,5-10,5 cm compr., pilosos, ráquis, ramos e pedicelos escabros e/ou pilosos, axilas pilosas. Espiguetas pareadas, $3-5 \times$ $1 \mathrm{~mm}$, lanceoladas, agudas; gluma inferior 1,8-4,5 mm compr., triangular, aristulada, escabra na nervura central, margens glabras a ciliadas, 3-nervada; gluma superior 3,2-4,5 mm compr., lanceolada, aristulada, escabra na nervura central e no ápice, margens glabras, 5-nervada; lema inferior neutro a estaminado, 2,8-4 mm compr., lanceolado, agudo, escabro no ápice, margens glabras, 5-nervado; pálea inferior 1-3 mm compr., lanceolada, aguda, escabra nas nervuras, 2-nervada; antécio superior 1,7-3,2 mm compr., oblongo-elíptico a lanceolado, agudo a obtuso, glabro, liso, castanho-claro a castanho, com cicatrizes na base do lema, 0,2-0,5 mm compr. Frutos não analisados.

Material selecionado: trilha da pousada, 28.II.2007, fl., A.C. Mota 226 (HUEFS); trilha da caixa d'água, 15.III.2008, fl., A.C. Mota 238 (HUEFS); trilha da torre, 20.IV.2008, fl., A.C. Mota 253 (HUEFS). 
Ichnanthus pallens é semelhante a I. tenuis (J. Presl \& C. Presl) Hitchc. \& Chase, tanto nos caracteres vegetativos quanto reprodutivos, com sobreposição em muitos deles. Entre os espécimes coletados na área de estudos, os materiais de $I$. pallens apresentam panículas com ramos primários de maior comprimento (6-17 vs. 1,4-5 cm compr.). Além disso, em I. pallens as inflorescências são mais ramificadas, apresentando ramos primários e secundários, enquanto que em I. tenuis as inflorescências apresentam apenas ramos primários.

Foram observados pelo menos três morfotipos distintos entre os materiais de $I$. pallens, que variam entre si em relação ao indumento das folhas, número de ramos primários e comprimento das espiguetas. Várias categorias infraespecíficas são propostas para I. pallens (e.g., variedade, "modo", "tipo"), mas os materiais da área de estudos não foram satisfatoriamente enquadrados em nenhuma delas. Por esse motivo, I. pallens foi considerada aqui como um táxon bastante polimórfico.

Ichnanthus pallens ocorre em todas as regiões do Brasil (Boechat 2005). Na área de estudos, suas populações ocorrem no interior, em clareiras e bordas da floresta, desde áreas com baixa até alta luminosidade. Foi observada em floração durante todo o ano.

5.4 Ichnanthus tenuis (J. Presl \& C. Presl) Hitchc. \& Chase, Contr. U.S. Natl. Herb. 18(7): 334. 1917.

Fig. 3j-1

Plantas perenes, decumbentes, radicantes nos nós inferiores, ca. $30 \mathrm{~cm}$ alt., entrenós glabros a pilosos, nós pilosos a hirsutos. Folhas com bainhas glabras a hirsutas, margens ciliadas; lígula membranoso-ciliada, 1-2,5 mm compr.; lâminas 1,14,3 ×0,3-1,1 cm, elíptico-lanceolada, lanceolada a oval-lanceolada, ápice acuminado, base subcordada, assimétrica, escabras ou hirsutas em ambas as faces, margens escabras, 4-8 nervuras secundárias. Inflorescências $1,4-5 \times 0,5-4 \mathrm{~cm}$, paniculadas, abertas, laxas, apenas com ramos primários, pedúnculos $0,7-6,5 \mathrm{~cm}$ compr., escabros e esparso-piloso, ráquis escabra, ramos escabros, axilas dos ramos pilosas, pedicelos escabros.
Espiguetas pareadas, 3-4 × 1,5 $\mathrm{mm}$, lanceoladas, agudas; gluma inferior $2-4 \mathrm{~mm}$ compr., triangular, aristulada, pilosa e/ou escabra nas nervuras, margens glabras, 3-nervada; gluma superior 3,5-4 $\mathrm{mm}$ compr., lanceolada, aristulada, esparso-pilosa e/ou escabra na nervura central, margens glabras, 5-nervada; lema inferior neutro, 2,5-4 mm compr., lanceolado, agudo, escabro na nervura central, margens glabras, 5-nervado; pálea inferior 1,5-2 mm compr., lanceolada, ápice agudo a obtuso, glabra a escabra nas nervuras, margens glabras, 2-nervada; antécio superior 1,8-2 $\mathrm{mm}$ compr., elíptico a oblongo-elíptico, arredondado, glabro, liso, castanho-claro a castanho, com cicatrizes à base do lema, ca. 0,5 mm compr. Frutos não analisados. Material selecionado: trilha da torre, 30.VI.2007, fl., A.C. Mota 72 (HUEFS); trilha da bapeba, 25.I.2008, fl., A.C. Mota 215(HUEFS); trilha da casa para o Centro de Pesquisa, 28.II.2008, fl., A.C. Mota 230 (HUEFS).

Ichnanthus tenuis é um táxon de difícil delimitação, com muita sobreposição em relação a I. pallens, conforme comentários inseridos nesta última espécie. A estrutura da inflorescência de ambas permite certa separação, mas os limites entre essas duas espécies têm sido questionados por muitos autores (e.g., Oliveira et al. 2003; Boechat 2005).

No Brasil, ocorre em todas as regiões, em interior e bordas de florestas (Boechat \& Lerina 2001). Na área de estudos, as populações de $I$. tenuis, assim como de I. pallens, ocorrem no interior, clareiras e bordas da floresta, sob as mesmas condições de luminosidade e também em estado fértil durante todo o ano.

6. Lasiacis (Griseb.) Hitchc., Contr. U.S. Natl. Herb. 15: 16.1910.

Lasiacisinclui 16 espécies distribuídas no sul da Flórida e México Central, Caribe, América Central e América do Sul (Davidse 1978). Apresenta plantas de aspecto bambusóide, com inflorescências paniculadas, abertas a contraídas, espiguetas oblíquas nos pedicelos, glumas e lema inferior tomentosos no ápice, tornando-se purpúreos até negros, na maturação.

Renvoize (1984) citou três espécies para a Bahia, duas das quais ocorrem na área de estudos.

\section{Chave para as espécies de Lasiacis}

1. Folhas com lígula de 0,4-0,7 mm compr., lâminas com 4-6 nervuras secundárias 6.1 L. divaricata

1. Folhas com lígula de 2-3 mm compr., lâminas com 8-10 nervuras secundárias 6.2 L. ligulata 
6.1 Lasiacis divaricata (L.) Hitchc., Contr. U.S. Natl. Herb. 15: 16. 1910.

Fig. 3m-p

Plantas perenes, cespitosas, arqueando no ápice, ou escandentes, ca. $150 \mathrm{~cm}$ alt., entrenós e nós glabros ou com uma faixa longitudinal pilosa. Folhas com bainhas pilosas ou glabras, margens ciliadas; lígula membranosa, 0,4-0,7 mm compr.; lâminas 3,6-8 × 0,5-1,6 cm, lanceoladas, ápice acuminado, base arredondada, levemente assimétrica, pilosa em ambas as faces, margens escabras, 4-6 nervuras secundárias. Inflorescências 3,6-6 ×2$4 \mathrm{~cm}$, paniculadas, abertas, pedúnculos ca. $1 \mathrm{~cm}$ compr., glabros, ráquis e ramos escabros, axilas dos ramos pilosas, pedicelos escabros a pilosos. Espiguetas 3,8-4 mm compr., obovais, obtusas; gluma inferior 1,8-2 mm compr., oval, aguda, escabra, margens tomentosas no ápice, 11-nervada; gluma superior 3-3,2 mm compr., oboval, acuminada, escabra, margens tomentosas no ápice, 11-nervada; lema inferior neutro, 3,2-3,7 mm compr., oboval, agudo, glabro, margens tomentosas no ápice, 11nervado; pálea inferior 2-2,5 mm compr., lanceolada, obtusa, tomentosa, margens glabras, 2-nervada; antécio superior 3-3,5 $\mathrm{mm}$ compr., oboval, obtuso, margens tomentosas no ápice, longitudinalmente papiloso. Frutos não analisados.

Material selecionado: trilha da pousada, 14.IV.2007, fl., A. M. Amorim et al. 6998 (CEPEC); trilha da torre, 15.III.2008, fl. A.C. Mota 241 (HUEFS); trilha da caixa d'água, 20.IV.2008, fl., A.C. Mota 251 (HUEFS).

Lasiacis divaricata e L. ligulata Hitchc. \& Chase são muito semelhantes em relação ao hábito e demais caracteres vegetativos e reprodutivos. É possível diferenciá-las principalmente pelo comprimento da lígula, muito mais curta na primeira.

Está amplamente distribuída no Brasil, em floresta pluvial, bordas de florestas e em florestas secundárias (Santos \& Sano 2001). Na área de estudos, as touceiras ocorrem nas bordas da floresta, sob baixa intensidade luminosa. Foi coletada fértil nos meses de março a maio.

6.2 Lasiacis ligulata Hitchc. \& Chase, Contr. U.S. Natl. Herb. 18(7): 337. 1917. Fig. 3q-t

Plantas perenes, cespitosas, arqueando no ápice, ou escandentes, 2-7 m alt., entrenós e nós glabros ou com uma faixa longitudinal pilosa. Folhas com bainhas glabras, margens ciliadas; lígula membranosa, 2-3 mm compr.; lâminas 3,6$12,8 \times 0,6-2,1 \mathrm{~cm}$ compr., lanceoladas, ápice acuminado, base arredondada, levemente assimétrica, pilosa em ambas as faces, margens escabras, 8-10 nervuras secundárias. Inflorescências 5,7-16 × 5-12 cm, paniculadas, abertas, pedúnculos ca. $1 \mathrm{~cm}$ compr., glabros; ráquis, ramos, axilas e pedicelos escabros. Espiguetas 3,5$3,8 \mathrm{~mm}$ compr., obovais, obtusas; gluma inferior 1,5-2 mm compr, oval, aguda, escabra, margens tomentosas no ápice, 9-11-nervada; gluma superior 2,5-3,2 mm compr, oboval, acuminada, escabra, margens tomentosas no ápice, 11nervada; lema inferior neutro, 3-3,2 mm compr., oboval, agudo, glabro, margens tomentosas no ápice, 11-nervado; pálea inferior 2-2,5 mm compr., oboval, obtusa, tomentosas, margens glabras, 2nervada; antécio superior 2,8-3 $\mathrm{mm}$ compr., oboval, obtuso, castanho, margens tomentosas no ápice, longitudinalmente papiloso. Frutos não analisados.

Material selecionado: trilha de acesso a RPPN, 25.III.2007, fl. A. M. Amorim et al. 6956 (CEPEC); trilha da pousada em direção a cachoeira, 26.V.2007, fl. A.C. Mota et al. 57 (CEPEC).

Embora semelhante a L. divaricata conforme discutido acima, L. ligulata apresentou, na área de estudos, inflorescências muito mais densas e tipicamente com espiguetas purpúreas a negras na maturação, além da típica lígula bem desenvolvida.

No Brasil ocorre em florestas e margens de córregos (Santos \& Sano 2001). Na área de estudos, as touceiras de L. ligulata ocorrem nas bordas da floresta, sob alta intensidade luminosa. Foi coletada fértil nos meses de janeiro, março, maio, agosto e dezembro.

7. Ocellochloa Zuloaga \& Morrone, Systematic Botany 34 (4): 684-692. 2009.

Ocellochloa foi recentemente desmembrado de PanicumL. e inclui 12 espécies distribuídas do México até a Argentina, comumente encontrada em florestas ou suas margens, assim como em campos rupestres e cerrados, desde o nível do mar até 2.800 $\mathrm{m}$ de altitude (Sede et al. 2009). Apresentam inflorescências paniculadas com poucos ou muitos ramos unilaterais, espiguetas pareadas curtopediceladas, gluma inferior 3-(5) nervada, gluma superior menor ou subugual ao lema, 5-(7) nervado, lema inferior com ou sem 1-2(-3) pares de glândulas (ocelos), antécio superior liso e não apiculado.

No Brasil ocorrem oito espécies, das quais quatro foram confirmadas para a Bahia (Sede et al. 2009); na área de estudos, está representado por duas espécies. 


\section{Chave para as espécies de Ocellochloa}

1. Plantas robustas, ca. $180 \mathrm{~cm}$ alt.; inflorescências ca. $32 \mathrm{~cm}$ compr., espiguetas com gluma inferior 5-nervada, gluma superior 7-nervada, gluma superior e lema inferior escabros e com tricomas longos e esparsos, margens ciliadas 7.1 O. rudis

1'. Plantas delicadas, 30-90 cm alt.; inflorescências 6,5-11,2 cm compr., espiguetas com gluma inferior 3-nervada, gluma superior 5-nervada, gluma superior e lema inferior apenas com tricomas escabros, margens glabras 7.2 O. stolonifera

7.1 Ocellochloa rudis (Nees) Zuloaga \& Morrone, Syst. Bot. 34(4): 690. $2009 . \quad$ Fig. 4a-c

Plantas perenes, decumbentes, radicante nos nós inferiores, ca. $180 \mathrm{~cm}$ alt., entrenós glabros, nós pilosos. Folhas com bainhas escabras, margens glabras; lígula membranoso-ciliada, ca. 0,2 mm compr.; lâminas $20-28 \times 1,8-4 \mathrm{~cm}$, lanceoladas, ápice acuminado, base arredondada, simétrica, escabra em ambas as faces, margens escabras, 20-26-nervuras secundárias. Inflorescências ca. $32 \times 9,5 \mathrm{~cm}$, paniculadas, com ramos unilaterais, pedúnculos ca. $22 \mathrm{~cm}$ compr, escabros; ráquis, ramos e pedicelos escabros, axilas pilosas. Espiguetas pareadas, ca. $2 \times 1,5 \mathrm{~mm}$, ovais, agudas; gluma inferior 1-1,8 mm compr., oval, acuminada, glabra, margens glabras, 5-nervada; gluma superior ca. 2 mm compr., oval, obtusa, escabra, com tricomas longos esparsos, margens ciliadas, 7-nervada; lema inferior estaminado, ca. $2 \mathrm{~mm}$ compr., oval, acuminado, escabro e com tricomas longos esparsos, margens ciliadas, 5-nervado; pálea inferior ca. 1,8 mm compr., lanceolada, aguda, com tricomas nas nervuras; antécio superior ca. 1,8 mm compr., lanceolado, agudo, glabro, liso, castanho-claro. Frutos não analisados.

Material selecionado: mirante, 28.II.2008, fl., A.C. Mota 233 (HUEFS).

Ocellochloa rudis pode ser facilmente diferenciada de $O$. stolonifera (Poir.) Zuloaga \& Morrone, principalmente pelo porte mais robusto e inflorescências bem desenvolvidas.

Esta espécie é conhecida apenas para o Brasil, citada para o Distrito Federal, Regiões Sudeste e Sul, sendo comum em interior e bordas de florestas (Zuloaga \& Sendulsky 1988; Zuloaga et al. 2001a). Este corresponde ao primeiro registro da espécie para a Bahia. Na área de estudos, foi encontrada no interior da floresta, sob baixa intensidade luminosa, tendo sido coletada em floração apenas no mês de fevereiro.

7.2 Ocellochloa stolonifera (Poir.) Zuloaga \& Morrone, Syst. Bot. 34(4): 690. $2009 . \quad$ Fig. 4d-f

Plantas perenes, estoloníferas, $30-90 \mathrm{~cm}$ alt., entrenós e nós glabros a pubescentes. Folhas com bainhas glabras, margens ciliadas; lígula membranosa, ca. 0,2 mm compr.; lâminas 3,6-8,4×1,1-2,7 cm, ovais, ápice acuminado, base subcordada, assimétrica, pubérulas em ambas as faces, margens escabras, 812-nervuras secundárias. Inflorescências 6,5-11,2× 2-4cm, paniculadas, com ramos unilaterais, inclusas a pedunculadas, pedúnculos $0,7-3 \mathrm{~cm}$ compr., pubescentes; ráquis, ramos, axilas e pedicelos pilosos. Espiguetas pareadas, $1,8-2,1 \times 0,8 \mathrm{~mm}$, lanceoladas, agudas; gluma inferior $0,8 \mathrm{~mm}$ compr., oval, aguda, escabra na nervura central, margens glabras, 3-nervada; gluma superior 1,7-1,8 mm compr., lanceolada, aguda, escabra no ápice, margens glabras, 5-nervada; lema inferior neutro, 1,8-2 mm compr., lanceolado, acuminado, escabro no ápice, margens glabras, 5nervado; pálea inferior ca. 0,9 mm compr., lanceolada, aguda, escabras nas nervuras, 2-nervada; antécio superior 0,9-1 mm compr. lanceolado, agudo, glabro, liso, estramíneo. Frutos não analisados.

Material selecionado: próximo à pousada, 15.III.2007, fl., R.P. Oliveira et al. 1228 (CEPEC).

No Brasil, Ocellochloa stolonifera ocorre nas Regiões Norte e Centro-Oeste, na Bahia e do Rio de Janeiro até Rio Grande do Sul, em interior de mata (Zuloaga et al. 2001a). Na área de estudos, as populações ocorrem sob a sombra das bordas da floresta, em locais muito úmidos, com baixa intensidade luminosa. Foi coletada fértil nos meses de dezembro e março.

\section{Panicum L., Sp. Pl. 1: 55.1753.}

Panicum compreendia ca. 600 espécies (Zuloaga 1987), porém, com base em estudos filogenéticos, vários subgêneros e seções foram elevados a gêneros, como Steinchisma Raf. (Zuloaga et. al. 1998), Megathyrsus (Pilg.) B.K. Simon \& S.W.L. Jacobs (Simon \& Jacobs 2003), Dicanthelium (Hitchc. \& Chase) Gould. (Aliscioni et al. 2003), e, mais recentemente, Hopia Zuloaga \& Morrone (Zuloaga et al. 2007), Parodiophyllochloa Zuloaga \& Morrone (Morrone et al. 2008) e Ocellochloa Zuloaga \& Morrone (Sede et al. 2009). 


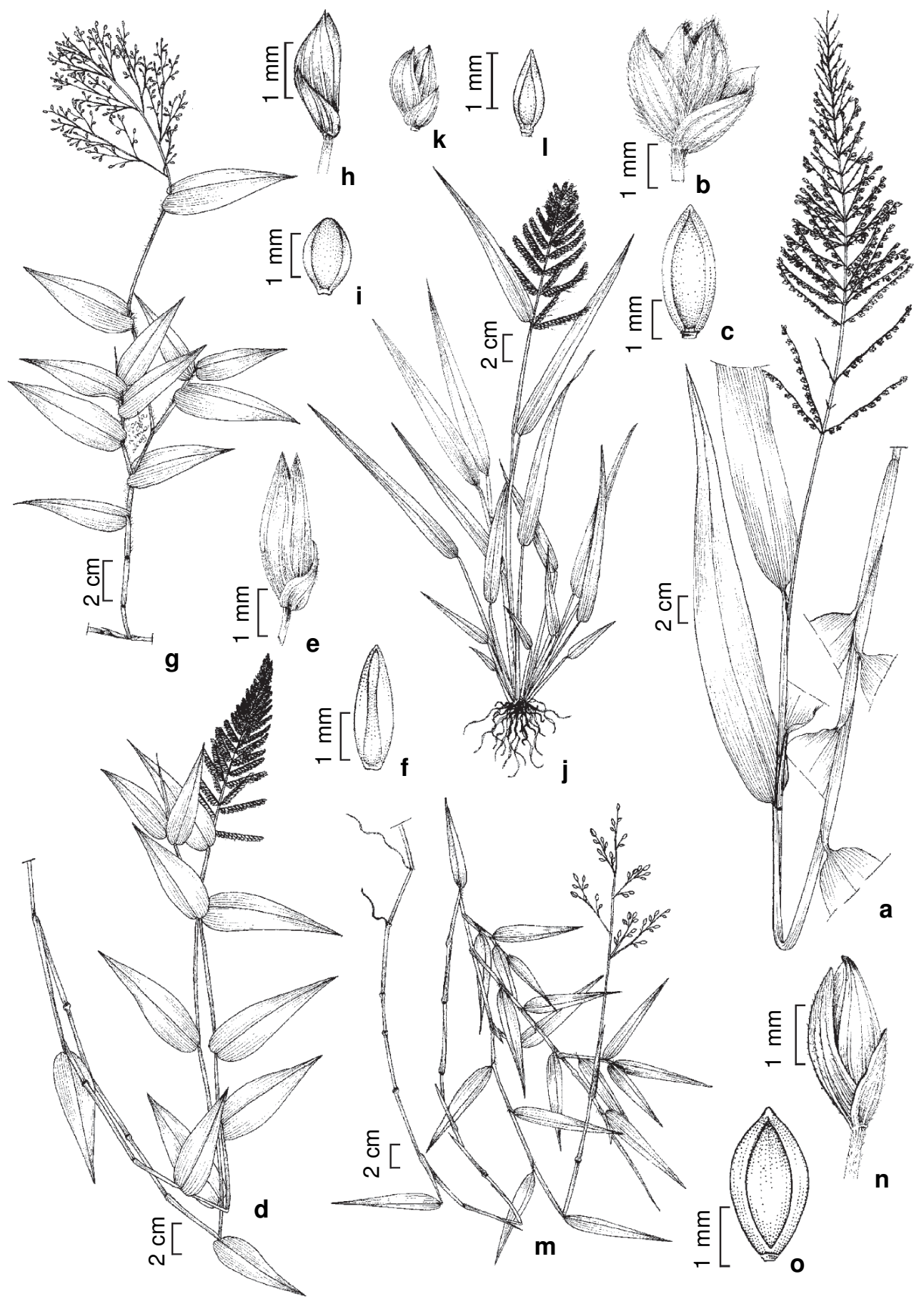

Figura 4 - a-c. Ocellochloa rudis - a. hábito; b. espigueta; c. antécio superior, vista da pálea (A.C. Mota 233 (HUEFS)). d-f. Ocellochloa stolonifera - d. hábito; e. espigueta; f. antécio superior, vista da pálea (R.P. Oliveira et al. 1228(CEPEC)). g-i. Panicum brevifolium - g. hábito; h. espigueta; i. antécio superior, vista da pálea (A.C. Mota et al. 64 (CEPEC)).j-1. Panicum pilosum-j. hábito; k. espigueta; 1. antécio superior, vista da pálea (d A.C. Mota 216(HUEFS); e-f A.C. Mota 227(HUEFS)). m-o. Parodiophyllochloa cordovensis - m. hábito; n. espigueta; o. antécio superior, vista da pálea (A.C. Mota 178 (HUEFS)). Figure 4 - a-c. Ocellochloa rudis - a. habit; b. spikelet; c. anthecium, palea view (A.C. Mota 233 (HUEFS)). d-f. Ocellochloa stolonifera d. habit; e. spikelet; f. anthecium, palea view (R.P. Oliveira et al. 1228(CEPEC)). g-i. Panicum brevifolium - g. habit; h. spikelet; i. anthecium, palea view (A.C. Mota et al. 64 (CEPEC)). j-1. Panicum pilosum - j. habit; k. spikelet; 1. anthecium, palea view (d A.C. Mota 216 (HUEFS); e-f A.C. Mota 227 (HUEFS)). m-o. Parodiophyllochloa cordovensis - m. habit; n. spikelet; o. anthecium, palea view (A.C. Mota 178 (HUEFS)). 
Em sua delimitação atual, inclui ca. 100 espécies, amplamente distribuídas no mundo (Aliscioni et al. 2003), com inflorescências paniculadas, abertas a contraídas, espiguetas em longos pedicelos, ou mais raramente inflorescências paniculadas com ramos unilaterais e espiguetas curto-pediceladas; espiguetas com gluma inferior geralmente pequena e 3-9-nervada, gluma superior e lema inferior subiguais, (5)7-13nervados, antécio superior endurecido, liso ou papiloso, não apiculado.

Renvoize (1984) citou 64 espécies de Panicum para a Bahia, levando em conta o conceito amplo. $\mathrm{Na}$ área de estudos, o gênero está representado por apenas duas espécies, conforme a delimitação mais recente.

\section{Chave para as espécies de Panicum}

1. Folhas com lígula membranoso-ciliada, lâmina oval e de base cordada; espiguetas ca. 1,5 mm compr., ovais

1'. Folhas sem lígula, lâmina lanceolada e de base truncada; espiguetas 1-1,3 mm compr., elípticas

8.1 Panicum brevifolium L., Sp. Pl. 1: 59. 1753.

Fig. 4g-i

Plantas anuais, decumbentes, radicantes nos nós inferiores, ca. $70 \mathrm{~cm}$ alt., entrenós e nós glabros. Folhas com bainhas curto-escabras, margens ciliadas; lígula membranoso-ciliada, ca. $0,5 \mathrm{~mm}$ compr.; lâminas 5,2-8,6×1,2-2 cm, ovais, ápice acuminado, base cordada, assimétrica, face adaxial curto-escabra a pilosa, face abaxial glabra a pilosa na base ou na nervura central; margens escabras e ciliadas na base, 6-10 nervuras secundárias. Inflorescências 6,5-11,5×5-8,5 cm, paniculadas, pedúnculos $1,6-11 \mathrm{~cm}$ compr., glabros; ráquis, ramos, axilas e pedicelos curtoescabros. Espiguetas pareadas, $1,5 \times 1 \mathrm{~mm}$, ovais, agudas; gluma inferior ca. 1,5 $\mathrm{mm}$ compr., lanceolada, aguda, curto-escabra, margens glabras, 3-nervada; gluma superior ca. 1,5 mm compr., oval, aguda, curto-escabra, margens glabras, 5-nervada; lema inferior neutro ca. 1,5 mm compr., oval, acuminado, curto-escabro, margens glabras, 5-nervado; pálea inferior ausente; antécio superior ca. $1 \mathrm{~mm}$ compr., oval, agudo, glabro, liso, estramíneo. Frutos não analisados.

Material selecionado: trilha da bapeba, 27.V.2007, fl., A.C. Mota et al. 64 (CEPEC).

Panicum brevifolium é facilmente diferenciada de $P$. pilosum $\mathrm{Sw}$. pela lígula (membranoso-ciliada), que é ausente na segunda.

Nativa da África e Ásia, introduzida no Brasil, ocorrendo em lugares sombreados (Renvoize 1984). Na área de estudos, as touceiras ocorrem sob a sombra da borda da floresta, com baixa intensidade luminosa. Foi coletada fértil em maio e junho.
8.2 Panicum pilosum Sw., Prodr.: 22. 1788.

Fig. $4 \mathrm{j}-1$

Plantas perenes, estoloníferas, $65-78,5 \mathrm{~cm}$ alt., entrenós glabros, nós glabros a pubescentes. Folhas com bainhas glabras, margens glabras a ciliadas; lígula ausente; lâminas 8,4-25,5×0,8-1,5 cm compr., lanceoladas, ápice agudo a acuminado, base truncada, simétrica, às vezes assimétrica, face adaxial esparso-pilosa e curto-escabra, face abaxial glabra, margens curto-escabras, 6 nervuras secundárias. Inflorescências 5,2-23 × 1,6-5 cm, paniculadas com ramos unilaterais, inclusas a pedunculadas, pedúnculos 5-15 cm, pilosos; ráquis, axilas e pedicelos curtoescabros, ramos pilosos. Espiguetas pareadas, 1$1,3 \times 0,5 \mathrm{~mm}$, elípticas, agudas; gluma inferior ca. $0,8 \mathrm{~mm}$ compr., oval, aguda, curto-escabra na nervura central, margens glabras, 3-nervada; gluma superior ca. 1,1 mm compr., oval-elíptica, aguda, curto-escabra na nervura central, margens glabras, 5-nervada; lema inferior neutro, ca. 1,2 mm compr., oval-elíptico, agudo, curto-escabro na nervura central, margens glabras, 3-nervado; pálea inferior ca. $0,8 \mathrm{~mm}$ compr., linear, aguda, glabra, enérvea; antécio superior ca. $1 \mathrm{~mm}$ compr., elíptico, agudo, glabro, liso, estramíneo. Frutos não analisados.

Material selecionado: trilha da torre, 30.VI.2007, fl., A.C. Mota 80 (HUEFS).

No Brasil, Panicum pilosum está distribuída em todo o país, em locais sombreados de borda ou interior de floresta, solos úmidos, menos comumente em campo aberto (Zuloaga et al. 2001a). Na área de estudos, ocorre nas bordas e clareiras da floresta, sob baixa a alta intensidade luminosa; foi observada florida durante todo o ano. 
9. Parodiophyllochloa Zuloaga \& Morrone, Syst. Bot. 33(1): 66-76. 2008.

Recentemente segregado de Panicum, Parodiophyllochloa inclui seis espécies distribuídas do México à Argentina, predominantes em lugares úmidos e sombreados (Morrone et al. 2008). É caracterizado por apresentar inflorescências paniculadas, abertas e laxas, com espiguetas pareadas, e antécio superior apiculado, papiloso. Na área de estudos, está representado por uma espécie.

9.1 Parodiophyllochloa cordovensis (E. Fourn.) Zuloaga \& Morrone, Syst. Bot. 33(1): 69-70. 2008.

Fig. $4 \mathrm{~m}-\mathrm{o}$

Plantas perenes, decumbentes, radicantes nos nós inferiores, ca. $200 \mathrm{~cm}$ alt., entrenós glabros, nós pilosos. Folhas com bainhas escabras, margens ciliadas; lígula membranosa-ciliada, ca. $0,5 \mathrm{~mm}$ compr.; lâminas 8-16×1-1,6 cm compr., ovais, ápice acuminado, base cordada, assimétrica, escabras e com tricomas longos esparsos ou concentrados apenas na base em ambas as faces, margens escabras, 8-12 nervuras secundárias. Inflorescências 7-21 ×1,5-2 cm, paniculadas, abertas, laxas, inclusas, ráquis e ramos escabros a pilosos. Espiguetas pareadas, ca. $3 \times$ $1,5 \mathrm{~mm}$ elípticas, agudas; gluma inferior $2-2,5 \mathrm{~mm}$ compr., oval, aguda, curto-escabra no ápice, margens glabras a pilosas, 3-nervada; gluma superior 2,52,8 mm compr., lanceolada, aguda, curto-escabras a pilosas, margens curto-escabras no ápice, 7-nervada; lema inferior 2,8-3 mm compr., oval, agudo, curtoescabro no ápice, margens glabras, 7-nervado; pálea inferior ausente; antécio superior 2,8-3 mm compr., elíptico, apiculado, glabro, papiloso, estramíneo.
Material selecionado: trilha da torre, 24.XI.2007, fl., A.C. Mota 178 (HUEFS); trilha da bapeba, 28.II.2008, fl., A.C. Mota 234 (HUEFS).

Parodiophyllochloa cordovensis distinguese das demais espécies de Poaceae ocorrentes na área de estudos pelas espiguetas com gluma inferior 3-nervada, além de antécio superior apiculado e papiloso.

Morrone et al. (2008) citaram esta espécie para o Brasil, sob Panicum cordovense E. Fourn., indicando sua distribuição para as Regiões Centro-Oeste, Sudeste e Sul. Portanto, trata-se do primeiro registro dessa espécie tanto para a Bahia, quanto para a região Nordeste. Foram encontradas na área de estudos populações no interior da mata sob baixa intensidade luminosa, e em floração de novembro a abril.

10. Paspalum L., Syst. Nat. (ed 10) 2: 846, 855, 1359. 1759.

Paspalum compreende ca. 330 espécies (Clayton \& Renvoize 1986), distribuídas em regiões tropicais e subtropicais do globo (Oliveira \& Valls 2001). Caracteriza-se pelas inflorescências racemosas, com ramos unilaterais espiciformes conjugados ou alternos, menos comumente digitados; espiguetas geralmente plano-convexas, pareadas ou solitárias, geralmente sem gluma inferior, gluma e lema superiores adaxiais à ráquis, lema superior coriáceo, sem margens hialinas, cobrindo levemente a pálea.

No Brasil, está representado por ca. 220 espécies (Canto-Dorow et al. 1996), 48 das quais foram citadas para a Bahia (Renvoize 1984). Na área de estudos este é o gênero mais diverso, sendo representado por sete espécies.

\section{Chave para as espécies de Paspalum}

1. Inflorescências com apenas um ramo.

2. Espiguetas com gluma inferior dissimilar em cada par [gluma inferior da espigueta superior reduzida (ca. 0,4 mm compr.), e conspícua na espigueta inferior (ca. $1 \mathrm{~mm}$ compr.)] 10.3 P. decumbens

2'. Espiguetas gluma inferior ausente 10.5 P. nutans

1'. Inflorescências com dois ou mais ramos.

3. Inflorescências com dois ramos.

4. Folhas com bainhas glabras; lâminas com 10-14-nervuras secundárias; gluma superior com margens ciliadas, 2-nervada; lema inferior 2-nervado; antécio superior glabro

10.1 P. conjugatum

4'. Folhas com bainhas pilosas; lâminas com 2-8-nervuras secundárias; gluma superior com margens glabras, 3-nervada; lema inferior 3-nervado; antécio superior pubescente nas margens e no ápice do lema superior 10.7 P. pumilum

3'. Inflorescências com mais de dois ramos.

5. Inflorescências com 40-47 ramos unilaterais espiciformes 10.4 P. millegrana 
5'. Inflorescências com até 3-19 ramos unilaterais espiciformes.

6. Bainhas foliares glabras; lâminas com base atenuada; inflorescências com 3-8 ramos unilaterais espiciformes; espiguetas 1,8-2 mm compr. $10.2 P$. corcovadense

6'. Bainhas foliares híspidas e escabras; lâminas com base truncada; inflorescências com 15-19 ramos unilaterais espiciformes; espiguetas $0,9-1 \mathrm{~mm}$ compr. 10.6 P. paniculatum

10.1 Paspalum conjugatum P.J. Bergius, Acta Helv. Phys.-Math. 7: 129, pl. 8. 1772.

Fig. 5a-c

Plantas perenes, estoloníferas, $35-70 \mathrm{~cm}$ alt., entrenós glabros, nós glabros, raramente hirsutos. Folhas com bainhas glabras, margens ciliadas no ápice; lígula membranosa, ca. 0,2 mm compr.; lâminas 7-24,1 ×0,6-1,2 cm, linear-lanceoladas, ápice agudo, base arredondada, simétricas, glabras a esparsopilosas, margens ciliadas e escabras, 10-14-nervuras secundárias. Inflorescências 3-13,5 cm compr., com 2 ramos unilaterais espiciformes conjugados a subconjugados, pedúnculos 2,5-6 cm compr., glabros; ráquis, axilas e pedicelos glabros. Espiguetas solitárias, $1-1,2 \times 0,8-0,9 \mathrm{~mm}$, obovais, plano-convexas, obtusas, curto-apículada; gluma inferior ausente; gluma superior 1-1,2 mm compr., oboval, obtusa, curto-apiculada, glabra, margens ciliadas, 2-nervada; lema inferior neutro, 1-1,2 mm compr., oboval, obtuso, curto-apiculado, glabro, margens glabras, 2-nervado; pálea inferior ausente; antécio superior $0,9-1,1 \mathrm{~mm}$ compr, oboval, obtuso, curto-apiculado, castanho-claro, glabro, longitudinalmente papiloso. Frutos não analisados. Material selecionado: trilha principal, 30.VI.2007, fl., A.C. Mota 79 (HUEFS); trilha da pousada, 24.XI.2007, fl., A.C. Mota 186(HUEFS).

Paspalum conjugatum e P. pumilum Nees. apresentam inflorescências racemosas com dois ramos conjugados a subconjugados no ápice do colmo, e espiguetas solitárias. Entretanto, podem ser diferenciadas principalmente pelo hábito, ápice da lamina foliar, posição dos racemos no colmo e pilosidade das espiguetas.

No Brasil ocorre em todo o país, comumente em áreas alteradas, em solos drenados e brejosos (Oliveira \& Valls 2001). Na área de estudos forma grandes touceiras na borda da floresta, sob alta intensidade luminosa. Foi observada em floração durante todo o ano.

10.2 Paspalum corcovadense Raddi, Agrostogr. Bras. 2: 27. 1823. Fig. 5d-f

Plantas perenes, cespitosas, 0,4-1,5 m alt., entrenós e nós glabros. Folhas com bainhas glabras, margens ciliadas; lígula membranosa, $0,2-0,4 \mathrm{~mm}$ compr.; lâminas 11,2-43,2×0,8-1,9 cm, lanceoladas a oblanceoladas, ápice acuminado, base atenuada, simétrica, face adaxial pubescente, com tricomas longos esparsos e denso-piloso a hirsuto na base, face abaxial pubescente, com tricomas longos esparsos, margens escabras a esparso-ciliadas, 12 14-nervuras secundárias. Inflorescências 11,5-17,5 $\times 6-19 \mathrm{~cm}, \mathrm{com} 3-8$ ramos unilaterais espiciformes alternos, inclusas a pedunculadas, pedúnculos 4$24 \mathrm{~cm}$ compr., glabros; ráquis e ramos glabros, axilas hirsutas, pedicelos escabros. Espiguetas pareadas, 1,8-2×0,8-1 mm, obovais, plano-convexas, obtusas, curto-apiculadas; gluma inferior ausente; gluma superior 1,7-1,8 mm compr., oboval, obtusa, pilosa, margens ciliadas, 5-nervada; lema inferior neutro, 1,4-1,7 mm compr., oboval, obtuso, curto-apiculado, piloso, margens ciliadas, 5-nervado; pálea inferior ausente; antécio superior 1,4-1,7 $\mathrm{mm}$ compr., oboval, obtuso, curto-apiculado, castanho, glabro, longitudinalmente papiloso. Frutos não analisados. Material selecionado: trilha da torre, 30.VI.2007, fl., A.C. Mota 76 (HUEFS); trilha da pousada, 25.VIII.2007, fl., F. M. Ferreira et al. 1310(CEPEC); trilha da bapeba, 28.II.2008, fl., A.C. Mota 228 (HUEFS).

Paspalum corcovadense pode ser diferenciada das demais espécies do gênero ocorrentes na área pelas lâminas foliares com base atenuada e inflorescências com 3-8 racemos unilaterais alternos.

No Brasil, distribui-se do Rio de Janeiro até Rio Grande do Sul, em florestas secundárias, brejos e restinga (Oliveira \& Valls 2001). Na área de estudos, suas populações ocorrem nas clareiras e bordas da floresta, sob baixa a alta intensidade luminosa. Foi observada em floração durante todo o ano.

\subsection{Paspalum decumbens Sw., Prodr.: 22. 1788.}

Fig. $5 \mathrm{~g}-\mathrm{j}$

Plantas perenes, decumbentes, radicantes nos nós inferiores, $20-40 \mathrm{~cm}$ alt., entrenós e nós glabros. Folhas com bainhas glabras, margens ciliadas; lígula membranosa, 0,2-0,3 mm compr.; lâminas 2,6-6,5× 0,5-2 cm, lanceoladas, ápice agudo, base arredondada, simétrica, face adaxial com tricomas longos esparsos, face abaxial pubescente, com tricomas longos esparsos, margens ciliadas e escabras, 10-12-nervuras secundárias. Inflorescências 1,4-3,6 cm compr., com 


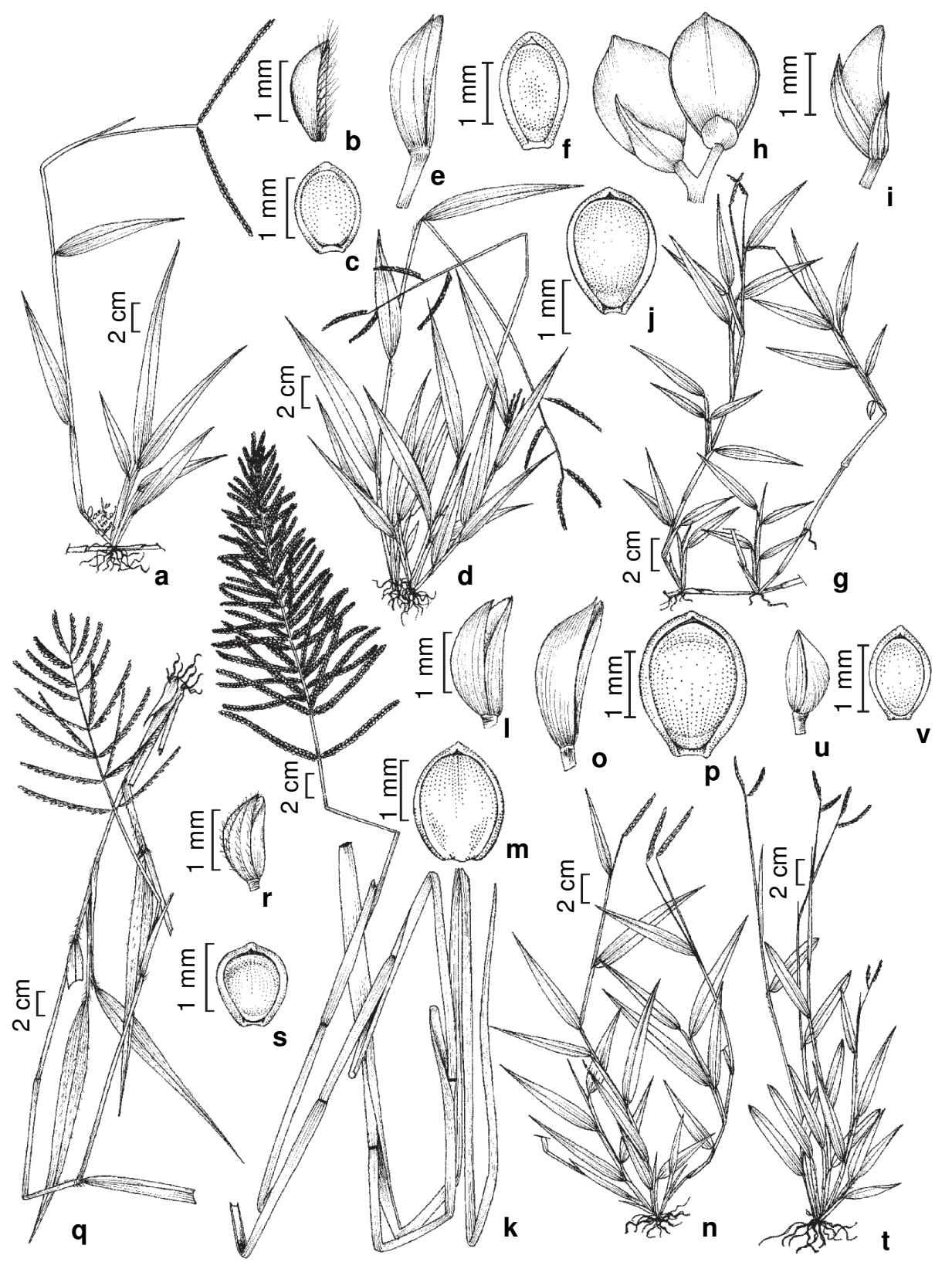

Figura 5 - a-c. Paspalum conjugatum - a. hábito; b. espigueta; c. antécio superior, vista da pálea (A.C. Mota 186 (CEPEC)). d-f. Paspalum corcovadense - d. hábito; e. espigueta; f. antécio superior, vista da pálea (A.C. Mota 196(HUEFS)). g-j. Paspalum decumbens - g. hábito; h. par de espiguetas, com gluma dissimilar; i. espigueta; j. antécio superior, vista da pálea (A.C. Mota 198 (HUEFS)). k-m. Paspalum millegrana - k. hábito; l. espigueta; m. antécio superior, vista da pálea (k A.C. Mota et al. 69(CEPEC); 1-m A.C. Mota 204 (HUEFS)). n-p. Paspalum nutans-n. hábito; o. espigueta; p. antécio superior, vista da pálea (n A.C. Mota 218 (HUEFS); o-p A.C. Mota 185 (HUEFS)). q-s.Paspalum paniculatum - q. hábito; r. espigueta; s. antécio superior, vista da pálea (A.C. Mota 189 (HUEFS)). t-v. Paspalum pumilum - t. hábito; u. espigueta; v. antécio superior, vista da pálea (A.C. Mota 183(CEPEC)). Figure 5 -a-c.Paspalum conjugatum - a. habit; b. spikelet; c. anthecium, palea view (A.C. Mota 186(CEPEC)). d-f.Paspalum corcovadense-d. habit; e. spikelet; f. anthecium, palea view (A.C. Mota 196 (HUEFS)). g-j. Paspalum decumbens-g. habit; h. spikelets paired, with dissimilar glume; i. spikelet; j. anthecium, palea view (A.C. Mota 198 (HUEFS)). k-m. Paspalum millegrana-k. habit; l. spikelet; m. anthecium, palea view (kA.C. Mota et al. 69 (CEPEC); 1-m A.C. Mota 204(HUEFS)). n-p. Paspalum nutans - n. habit; o. spikelet; p. anthecium, palea view (n A.C. Mota 218 (HUEFS); o-p A.C. Mota 185(HUEFS)). q-s. Paspalum paniculatum - q. habit; r. spikelet; s. anthecium, palea view (A.C. Mota 189 (HUEFS)). t-v. Paspalum pumilum -t. habit; u. spikelet; v. anthecium, palea view (A.C. Mota 183 (CEPEC)). 
1 ramo unilateral espiciforme, pedúnculos $1-9,5 \mathrm{~cm}$ compr., esparso-pilosos; ráquis esparso-pilosas, pedicelos escabros. Espiguetas pareadas, 1,1-1,7 $\times$ 0,8-0,9 mm, obovais, plano-convexas, obtusas, apiculadas; gluma inferior dissimilar em cada par, gluma inferior da espigueta superior ca. $0,4 \mathrm{~mm}$ compr., oval, obtusa, escabra, margens ciliadas no ápice, enérvea, gluma inferior da espigueta inferior ca. $1 \mathrm{~mm}$ compr., triangular, longo-acuminada a aristulada, escabra no ápice, margens ciliadas, 1nervada; gluma superior 1-1,2 mm compr., oboval, obtusa, glabra, margens glabras, 3-nervada; lema inferior neutro, 1,3-1,5 mm compr., oboval, obtuso, curto-apiculado, glabro, margens glabras, 3nervado; pálea inferior $0,7 \mathrm{~mm}$ compr., glabra, margens glabras, 2-nervada; antécio superior 1,2$1,5 \mathrm{~mm}$ compr., circular a oboval, obtuso, curtoapiculado, glabro, longitudinalmente papiloso, castanho-claro. Frutos não analisados.

Material selecionado: trilha principal, 15.III.2007, fl., R.P. Oliveira et al. 1232A (CEPEC); trilha da pousada em direção à cachoeira, 26.V.2007, fl., A.C. Mota et al. 59 (CEPEC).

Paspalum decumbens e P. nutans Lam. apresentam hábito semelhante, inflorescências com um único ramo e espiguetas pareadas. Em campo, podem ser de difícil delimitação, especialmente quando associadas. Uma diferença crucial nas espiguetas, mas não observada em campo, é que em $P$. decumbens a gluma inferior está presente e é dissimilar em cada par (reduzida na espigueta superior e conspícua na inferior), enquanto $P$. nutans não possui gluma inferior.

No Brasil, distribui-se nas Regiões CentroOeste, Nordeste e Sudeste, exclusivamente em florestas (Oliveira \& Valls 2001). Na área de estudos, ocorre no interior, clareiras e bordas da floresta, sob baixa a alta intensidade luminosa e florescendo durante o ano inteiro.

10. 4 Paspalum millegrana Schrad., Mant. 2: 175. 1824.

Fig. $5 \mathrm{k}-\mathrm{m}$

Plantas perenes, cespitosas, ca. 2,5 m alt., entrenós e nós glabros. Folhas com bainhas glabras, margens glabras; lígula membranosa, ca. $3 \mathrm{~mm}$ compr.; lâminas 42-93 ×0,9-1,3 cm, linear-lanceoladas, ápice longo-acuminado, base reta, simétrica, face adaxial escabra, face abaxial escabra e com tricomas longos, margens escabras, 14-16-nervuras secundárias. Inflorescências $23-24,5 \times 13,5-15 \mathrm{~cm}$, com 40-47 ramos unilaterais espiciformes alternos a opostos, pedúnculos ca. $70 \mathrm{~cm}$, glabros; ráquis escabra, ramos e axilas pilosos, pedicelos escabros. Espiguetas pareadas, ca. $2 \times 1,7 \mathrm{~mm}$, obovais, plano-convexas, obtusas, curto-apiculadas; gluma inferior ausente; gluma superior ca. $1,9 \mathrm{~mm}$ compr., oboval a circular, obtusa, apiculada, glabras, margens glabras, 3-nervada; lema inferior neutro, 1,9-2 mm compr., oboval, obtuso, apiculado, glabro, margens glabras, 3-nervado; pálea inferior ausente; antécio superior ca. $2 \mathrm{~mm}$ compr., oboval, obtuso, glabro, longitudinalmente papiloso, castanho-claro. Frutos não analisados.

Material selecionado: próximo à pousada, 25.I.2008, fl., A.C. Mota 204 (HUEFS).

Paspalum millegrana diferencia-se das demais espécies congenéricas presentes na área de estudos por apresentar maior porte (ca. 2,5 m alt.) e inflorescências mais desenvolvidas (40-47 ramos).

No Brasil ocorre em áreas alteradas, frequentemente em locais úmidos (Renvoize 1984). Uma única população foi encontrada em área alterada no entorno da floresta, sob alta intensidade luminosa e em floração durante todo o ano.

10.5 Paspalum nutans Lam., Tabl. Encycl. 1: 175. 1791.

Fig. 5n-p

Plantas perenes, decumbentes, radicantes nos nós inferiores, 15-60 cm alt., entrenós e nós glabros. Folhas com bainhas glabras, margens ciliadas; lígula membranosa, ca. 1 mm compr.; lâminas 3,4-11,4× 0,4-1 $(1,3) \mathrm{cm}$, linear-lanceoladas a lanceoladas, ápice agudo, base reta a arredondada, simétrica, face adaxial com tricomas longos esparsos, face abaxial pubescente e com tricomas longos esparsos, margens ciliadas e escabras, 8-10 nervuras secundárias. Inflorescências 1,6-4,5 cm compr., com 1 ramo unilateral espiciforme, inclusas a pedunculadas, pedúnculos 1,5-13 $\mathrm{cm}$ compr., esparso-pilosos; ráquis glabras, pedicelos escabros. Espiguetas pareadas, 1,6-1,8 $\times 1 \mathrm{~mm}$, obovais, planoconvexas, obtusas, apiculadas; gluma inferior ausente; gluma superior $(1,2) 1,5-1,6 \mathrm{~mm}$ compr., oboval, obtusa, glabra, margens com tricomas longos esparsos, 3-5-nervada; lema inferior neutro, 1,6$1,7 \mathrm{~mm}$ compr., oboval, obtuso, curto-apiculado, glabro, margens com tricomas longos esparsos, 35-nervado; pálea inferior ausente; antécio superior $(1,3) 1,4-1,5 \mathrm{~mm}$ compr., oboval, obtuso, curtoapiculado, glabro, longitudinalmente papiloso, castanho-claro. Frutos não analisados.

Material selecionado: trilha da pousada em direção à cachoeira, 26.V.2007, fl., A.C. Mota et al. 51 (CEPEC); trilha da torre, 30.VI.2007, fl., A.C. Mota 71 (HUEFS); trilha da bapeba, 25.I.2008, fl., A.C. Mota 211 (HUEFS); trilha da caixa d'água, 15.III.2008, fl., A.C. Mota 246 (HUEFS). 
No Brasil, Paspalum nutans ocorre do Pará e Pernambuco até Santa Catarina, em locais de meia sombra, em florestas secundárias baixas e florestas do litoral (Oliveira \& Valls 2001). Na área de estudos, as touceiras de $P$. nutans ocorrem no interior, clareiras e bordas da floresta, sob baixa e alta intensidade luminosa, tendo sido observada em floração durante todo o ano.

10.6 Paspalum paniculatum L., Syst. Nat. (ed. 10) 2:855. 1759 .

Fig. $5 \mathrm{q}-\mathrm{s}$

Plantas anuais, cespitosas, ca. $90 \mathrm{~cm}$ alt., entrenós glabros, nós densamente híspidos. Folhas com bainhas híspidas e escabras, margens híspidas e escabras; lígula membranosa, ca. 0,5 mm compr.; lâminas 8,7-27,5 × 1,2-1,7 cm, lanceoladas, ápice acuminado, base truncada, simétrica, híspidas e escabras em ambas as faces, margens híspidas e escabras, 14-22-nervuras secundárias. Inflorescências $8,5 \times 13 \mathrm{~cm}$, com 15-19 ramos unilaterais espiciformes alternos a opostos, pedúnculos ca. $21 \mathrm{~cm}$ compr., esparsamente híspidos; ráquis glabra, ramos escabros, axilas dos ramos híspidas, pedicelos escabros. Espiguetas pareadas, 0,9-1 ×0,7 $\mathrm{mm}$, circulares a obovais, plano-convexas, obtusas, curto-apiculadas; gluma inferior ausente; gluma superior $0,9-1 \mathrm{~mm}$ compr., circular a oboval, obtusa, curto-apiculada, pilosa, margens pilosas, 3-nervada; lema inferior neutro, 0,9-1 mm compr., esférico a oboval, obtuso, curto-apiculado, esparso-piloso, margens glabras, 3-nervado; pálea inferior ausente; antécio superior 0,9-1 mm compr., esférico a oboval, obtuso, curtoapiculado, glabro, longitudinalmente papiloso, castanho-claro. Frutos não analisados.

Material selecionado: trilha da bapeba, 27.V.2007, fl., A.C. Mota et al. 63 (CEPEC); próximo a pousada, 24.XI.2007, fl. A.C. Mota 189 (HUEFS).

Paspalum paniculatum é facilmente diferenciada por apresentar nós dos colmos, bainhas, lâminas foliares e pedúnculos híspidos. Além disso, possui inflorescências com 15-19 racemos unilaterais alternos a opostos.

No Brasil, ocorre em sombras de florestas, brejos e áreas alteradas (Renvoize 1984). Na área de estudos, suas touceiras ocorrem em partes alteradas no entorno da floresta, sob alta intensidade luminosa; foi coletada fértil nos meses de maio e novembro.

10.7 Paspalum pumilum Nees, Fl. Bras. Enum. Pl. 2(1): 52.1829.

Fig. 5t-v

Plantas perenes, cespitosas, $20-40 \mathrm{~cm}$ alt., entrenós e nós glabros. Folhas com bainhas pilosas, margens ciliadas; lígula membranosa, ca. 0,2 mm compr.; lâminas 2,2-7,8 ×0,2-0,5 cm, oblongo-lanceoladas, ápice obtuso, base arredondada, simétrica, pilosa em ambas as faces, margens pilosas e escabras, 2-8nervuras secundárias. Inflorescências 1,3-4 cm compr., com 2 ramos unilaterais espiciformes conjugados a subconjugados, pedúnculos 1,3-11,5 cm compr., esparso-pilosos a glabros; ráquis glabra, pedicelos escabros. Espiguetas solitárias, 1,2-1,5×0,8-1 mm, elípticas, plano-convexas, agudas, curto-apiculadas; gluma inferior ausente; gluma superior 1,2-1,5 mm compr., oboval, obtusa, curto-apiculada, glabra, margens glabras, 3-nervada; lema inferior neutro, 0,9-1,2 mm compr., oboval, obtuso, glabro, margens glabras, 3-nervado; pálea inferior ausente; antécio superior $0,9-1,2$ mm compr., oboval, obtuso, curtoapiculado, pubescente nas margens e ápice do lema superior, longitudinalmente papiloso, castanhoclaro. Frutos não analisados.

Material selecionado : próximo à torre, 24.XI.2007, fl., A.C. Mota 183 (HUEFS).

$\mathrm{O}$ aspecto geral da inflorescência de Paspalum pumilum é semelhante ao de $P$. conjugatum, porém apresenta espiguetas elípticas e agudas $v s$. obovais e obtusas em $P$. conjugatum.

É amplamente distribuída no Brasil, ocorrendo em margens de rios e lagoas (Renvoize 1984). Na área de estudos, suas touceiras ocorrem em ambientes alterados no entorno da floresta, porém exceto em áreas alagadas, sob alta intensidade luminosa. Foi coletada fértil apenas no mês de novembro.

11. Pennisetum Rich., Syn. Pl. 1: 72. 1805.

Pennisetuminlcui ca. 80 espécies distribuídas nas regiões tropicais e subtropicais de ambos os hemisférios (Boldrini 2001a). Caracteriza-se pelas inflorescências em panículas espiciformes, espiguetas solitárias ou em grupos de 2-3, subtendidas por um invólucro com 8-45 cerdas macias, longas e concrescidas em algum grau entre $\mathrm{si}$, caindo junto com as espiguetas.

Renvoize (1984) citou três espécies de Pennisetum para a Bahia, e na área de estudos, está representado por apenas uma delas.

11.1 Pennisetum purpureum Schumach., Beskr. Guin. Pl.: 44. 1827.

Fig. 6a-c

Plantas perenes, cespitosas, 1-2 m alt., entrenós glabros, nós hirsutos. Folhas com bainhas glabras, margens glabras; lígula membranoso-ciliada, ca. 4,2 mm compr.; lâminas $18-106 \times 1,1-5 \mathrm{~cm}$, lanceoladas, ápice acuminado, base reta, simétrica, escabra em ambas as faces, margens escabras, 816-nervuras secundárias. Inflorescências 6,5-32 × 


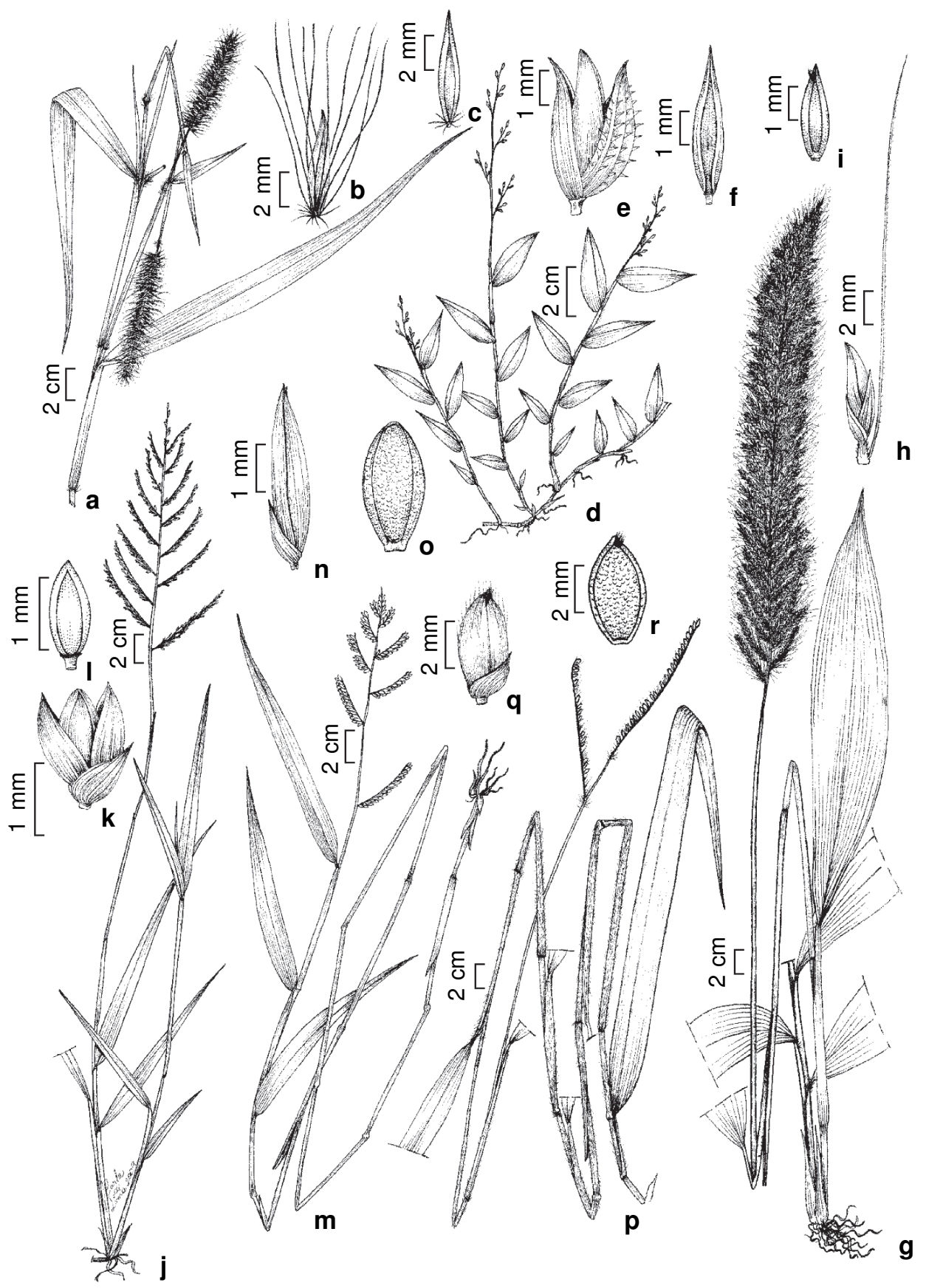

Figura 6 - a-c. Pennisetum purpureum - a. hábito; b. espigueta; c. antécio superior, vista da pálea (a M.M.M. Lopes et al. 835 (CEPEC); b-c A.M. Amorim et al. 5188 (CEPEC)). d-f. Pseudechinolaena polystachya - d. hábito; e. espigueta; f. antécio superior, vista da pálea (A.C. Mota 214 (HUEFS)). g-i. Setaria sulcata-g. hábito; h. espigueta e cerda; i. antécio superior, vista da pálea (A.C.Mota 252 (HUEFS)). j-1.Steinchisma laxa-j. hábito; k. espigueta; 1. antécio superior, vista da pálea(A.C. Mota 206 (HUEFS)). m-o. Urochloa arrecta - m. hábito; n. espigueta; o. antécio superior, vista da pálea(A.C. Mota 176 (HUEFS)). p-r. Urochloa brizantha - p. hábito; q. espigueta; r. antécio superior, vista da pálea (A.C. Mota 224(HUEFS)).

Figure 6 - a-c. Pennisetum purpureum - a. habit; b. spikelet; c. anthecium, palea view (a M.M.M. Lopes et al. 835 (CEPEC); b-c A. M. Amorim et al. 5188 (CEPEC)). d-f. Pseudechinolaena polystachya - d. habit; e. spikelet; f. anthecium, palea view (A.C. Mota 214(HUEFS)). g-i. Setaria sulcata - g. habit; h. spikelet and bristle; i. anthecium, palea view (A.C. Mota 252 (HUEFS)). j-1. Steinchisma laxa - j. habit; k. spikelet; 1. anthecium, palea view (A.C. Mota 206 (HUEFS)). m-o. Urochloa arrecta-m. habit; n. spikelet; o. anthecium, palea view (A.C. Mota 176 (HUEFS)). p-r. Urochloa brizantha - p. habit; q. spikelet; r. anthecium, palea view (A.C. Mota 224 (HUEFS)). 
2,5-4 cm, espiciformes, pedúnculos 2,5-3 cm compr., denso-pilosos no ápice; ráquis denso-pilosa. Espiguetas solitárias ou em grupos de 2-3, 5,5-6× $0,8 \mathrm{~mm}$, lanceoladas, acuminadas, subtendidas por 35-40 cerdas macias de 3-12 mm compr.; gluma inferior ausente; gluma superior $0,5-0,7 \mathrm{~mm}$ compr., triangular, aguda, escabra, margens escabras, 3nervada; lema inferior neutro, 2,7-3 mm compr., lanceolado, acuminado a apiculado, escabro, margens escabras no ápice, 3-nervado; pálea inferior ausente; lema superior ca. $5 \mathrm{~mm}$ compr., lanceolado, acuminado, escabro, margens escabras, 5-nervado; pálea superior ca. 4,5 mm compr., lanceolada, acuminada, escabra e pubescente na base, margens escabras, 2-nervada. Frutos não analisados.

Material selecionado: trilha da torre, 10.VII.2005, fl., A. M. Amorim et al. 5188 (CEPEC, HUEFS).

Pennisetum purpureum diferencia-se das demais Poaceae ocorrentes na área de estudos pelas inflorescências espiciformes, com espiguetas envolvidas por um invólucro constituído por muitas cerdas macias.

Nativa da África, introduzida no Brasil, ocupa clareiras de florestas secundárias, áreas úmidas e alteradas (Boldrini 2001a). Na área de estudos, as touceiras de $P$. purpureum ocorrem em ambientes alterados no entorno da floresta, sob alta intensidade luminosa. Foi coletada florida nos meses de junho e julho.

12. Pseudechinolaena Stapf, Fl. Trop. Afr. 9: 494. 1919.

Pseudechinolaena inclui seis espécies, uma pantropical e as demais endêmicas de Madagáscar (Renvoize 1984), todas de ambientes florestais (Longhi-Wagner 2001a). Apresenta inflorescências racemosas e espiguetas portando tricomas uncinados na gluma superior, na maturação e tricomas híspidos quando imaturas.

Renvoize (1984) citou Pseudechinolaena polystachya (Kunth) Stapf para a Bahia, a qual foi registrada na área de estudos.

12.1 Pseudechinolaena polystachya (Kunth) Stapf, Fl. Trop. Afr. 9: 495. 1919. Fig. 6d-f

Plantas perenes, decumbentes, radicantes nos nós inferiores, 10-20 cm alt., entrenós e nós pilosos. Folhas com bainhas esparso a densamente pilosas, margens ciliadas; lígula membranosa, ca. $1 \mathrm{~mm}$ compr.; lâminas 2,1-3,9×0,6-1,1 cm, ovais a elípticas, ápice agudo a acuminado, base subcordada, assimétrica, pilosas em ambas as faces, margens curto-escabras, às vezes ciliadas na base, 6 nervuras secundárias. Inflorescências 2,7-6,5 ×0,6-2,3 cm, com 3-5 ramos unilaterais espiciformes alternos, pedúnculos $0,7-$ $3 \mathrm{~cm}$, esparso-pilosos; ráquis, ramos, axilas e pedicelos curto-escabros. Espiguetas pareadas, ca. $4 \times 1,5 \mathrm{~mm}$, ovais, agudas; gluma inferior ca. $3 \mathrm{~mm}$ compr., oval, acuminada, curto-escabra, margens glabras, 3nervada; gluma superior ca. $3 \mathrm{~mm}$ compr., oval, aguda, curto-escabra e com tricomas uncinados de base tuberculada na maturação, margens curto-escabras, 5-nervada; lema inferior ca. 3,5 mm compr., lanceolado, agudo, curto-escabro, margens curto-escabras, 5nervado; pálea inferior ca. $3 \mathrm{~mm}$ compr., estreitolanceolada, aguda, curto-escabra, margens curtoescabras; antécio superior ca. $2 \mathrm{~mm}$ compr., lanceolado, acuminado, glabro, liso, estramíneo. Frutos não analisados.

Material selecionado: trilha da torre, 25.I.2008, fl. A.C. Mota 214 (HUEFS).

Esta espécie diferencia-se das demais de Poaceae da área de estudos pelas espiguetas com gluma superior coberta por tricomas uncinados na maturação.

No Brasil ocorre na região tropical, em interior de florestas úmidas, clareiras semi-sombreadas e áreas alteradas sombreadas (Longhi-Wagner 2001a). $\mathrm{Na}$ área de estudos, os indivíduos de $P$. polystachya ocorrem no interior da floresta mais fechada e em clareiras, sob baixa intensidade luminosa. Foi observada em estado fértil de novembro a janeiro.

13. Setaria P. Beauv., Ess. Agrostogr. 51: 178. 1812. Setaria compreende ca. de 125 espécies (Boldrini 2001b), distribuídas nas regiões tropicais, subtropicais e temperadas do mundo, com dois grandes centros de diversidade, a África Tropical e a América do Sul (Pensiero 1999). Caracteriza-se pelas inflorescências paniculadas, contraídas a espiciformes e espiguetas solitárias, subtendidas por uma ou mais cerdas longas, rígidas e livres entre si, persistentes na inflorescência após a queda das espiguetas maduras.

Renvoize (1984) citou nove espécies de Setaria para a Bahia, e na área de estudos, foi encontrada uma espécie, Setaria sulcata Raddi, não incluída entre as espécies referidas por esse autor.

13.1 Setaria sulcata Raddi, Agrostogr. Bras.: 50. 1823. Fig. 6g-i

Plantas perenes, cespitosas, eretas, ca. $2 \mathrm{~m}$ alt., entrenós glabros, nós pubescentes. Folhas com bainhas denso-pubescentes, margens ciliadas; lígula membranoso-ciliada ca. 3 mm compr.; lâminas 30,5- 
55,5 × 3,6-7,4 cm, plicadas, oblanceoladas, ápice acuminado, base atenuada, simétrica, face adaxial escabra, com alguns tricomas longos esparsos, face abaxial pubescente, escabra nas nervuras, densohirsuta na base, margens escabras, 20-28 nervuras secundárias. Inflorescências 13,5-40 × 2-4,5 cm, paniculadas, contraídas, congestas, pedúnculos ca. $60 \mathrm{~cm}$ compr., pubescentes; ráquis, ramos e axilas pubescentes, pedicelos escabros. Espiguetas solitárias, $2,8-3 \times 0,8 \mathrm{~mm}$, lanceoladas a ovallanceoladas, subtendidas por uma cerda rígida com ca. $6 \mathrm{~mm}$ compr.; gluma inferior ca. $1 \mathrm{~mm}$ compr., oval, obtusa, escabra no ápice ou glabra, margens glabras, 5-nervada; gluma superior ca. 1,8 mm compr., oval, obtusa, escabra no ápice, margens escabras no ápice, 5-nervada; lema inferior neutro, ca. 2,8 mm compr., lanceolado, acuminado, escabra no ápice, margens escabras no ápice, 5-nervado; pálea inferior ca. $0,4 \mathrm{~mm}$ compr., glabra, margens diminuto-ciliadas; antécio superior ca. 2,8 $\mathrm{mm}$ compr., lanceolado, curtoapiculado, escabro, transversalmente rugoso, castanho-claro. Frutos não analisados.

Material selecionado: trilha da pousada para centro de pesquisa, 27.V.2007, fl., A.C. Mota et al. 68 (CEPEC).

Setaria sulcata é bastante distinta das outras espécies de Poaceae encontradas na área de estudos, pelo hábito robusto, com lâminas foliares longas e plicadas. Além disso, com base nos caracteres reprodutivos, pode ser diferenciada das demais por cada espigueta estar subtendida por uma cerda rígida disposta no pedicelo. Muitos materiais de herbários com esta mesma morfologia estão geralmente identificados sob $S$. poiretiana (Schult.) Kunth, contudo este nome é encontrado na sinonímia de $S$. sulcata em Pensiero (2003).

É amplamente distribuída no Brasil, ocupando subosque e bordas de florestas primárias e secundárias (Boldrini 2001b, sob S. poiretiana). $\mathrm{Na}$ área de estudos, as grandes populações de $S$. sulcata foram encontradas apenas nas bordas sob a sombra da floresta, em locais úmidos, com alta intensidade luminosa. Foi observada em floração nos meses de abril e maio.

14. Steinchisma Raf., Bull. Bot (Geneve) 1:220.1830. Steinchisma compreende sete espécies distribuídas da América Central até a Argentina (Aliscioni et al. 2003), habitando lugares úmidos e abertos, margens de rios, pântanos ou áreas inundáveis, desde o nível do mar até $2600 \mathrm{~m}$ (Zuloaga et al. 1998). Constituía um subgênero de Panicum, e foi segregado deste com base em dados moleculares, anatômicos, morfológicos (ex.: pálea inferior expandida na maturação, sobressaindo o lema inferior, e presença de papilas em fileiras longitudinais, no lema superior) (Zuloaga et al. 1998).

No Brasil ocorre na Bahia e da Região CentroOeste até o Sul, em lugares brejosos (Zuloaga et al. 2001b). Renvoize (1984) citou três espécies para a Bahia (sob Panicum) e na área de estudos foi encontrada apenas uma delas.

14.1 Steinchisma laxa (Sw.) Zuloaga, Amer. J. Bot. 90(5): 817 (2003).

Fig. 6j-1

Plantas perenes, cespitosas, $55-85 \mathrm{~cm}$ alt., entrenós glabros a curto-escabros, nós glabros. Folhas com bainhas glabras, margens ciliadas; lígula membranosa-ciliada, ca. 0,5 mm compr.; lâminas 13,5$23,3 \times 0,6-0,8 \mathrm{~cm}$, lanceoladas, ápice acuminado, base arredondada, simétrica, pilosas e curto-escabras na base em ambas às faces, margens curto-escabras, 8-12 nervuras secundárias. Inflorescências 15,5-23,5 $\times 6,5-9 \mathrm{~cm}$, paniculadas, abertas, pedúnculos $1-4 \mathrm{~cm}$ compr., curto-escabro, ráquis, ramos, axilas e pedicelos curto-escabros. Espiguetas solitárias, ca. $1,5 \times 0,5 \mathrm{~mm}$, elíptico-lanceoladas, agudas; gluma inferior $0,5-0,8 \mathrm{~mm}$ compr, triangular, aguda, curtoescabra no ápice, margens glabras, 3-nervada; gluma superior ca. $1 \mathrm{~mm}$ compr., lanceolada, aguda, curtoescabra no ápice, margens glabras, 3-nervada; lema inferior neutro ou estaminado, ca $1,2 \mathrm{~mm}$ compr., lanceolado, agudo, curto-escabro no ápice, margens glabras, 3-nervado; pálea inferior ca. 1,2 mm compr., lanceolada, aguda, glabra, margens curtoescabras, expandida na maturação; antécio superior ca. $1 \mathrm{~mm}$ compr., lanceolado, agudo, glabro, papiloso longitudinalmente, estramíneo. Frutos não analisados. Material selecionado: trilha da caixa d'água, 24.XI.2007, fl., A.C. Mota 177 (HUEFS).

Esta espécie diferencia-se morfologicamente das demais pela pálea inferior expandida na maturação.

No Brasil ocorre em áreas abertas ou sombreadas, frequentemente em locais perturbados (Renvoize 1984). Na área de estudos, suas touceiras ocorrem nas bordas da floresta, sob alta luminosidade, e florescem de novembro a janeiro.

15. Urochloa P. Beauv., Ess. Agrostogr.: 52. 1812. Urochloa inclui 22 espécies, nove delas do Velho Mundo, e 13 americanas, distribuídas em regiões áridas, tropicais e subtropicais; na América, se estendem dos Estados Unidos à Argentina, sendo sete delas exclusivamente sulamericanas (Morrone \& Zuloaga 1992). Caracteriza- 
se pelas inflorescências racemosas, com ramos unilaterais espiciformes alternos, espiguetas solitárias, gluma e lema superior abaxiais à ráquis, especialmente caracterizado pelo antécio superior transversalmente rugoso.
Para o Brasil foram citadas 16 espécies, entre nativas e introduzidas, sob Brachiaria (Trin.) Griseb. (Sendulsky 1978). Renvoize (1984) citou três espécies para a Bahia, também sob Brachiaria, e na área de estudos, ocorrem duas delas.

\section{Chave para as espécies de Urochloa}

1. Nós e entrenós glabros; bainhas foliares glabras; lâminas foliares 7-19 cm compr.; inflorescências de 1-5,8 cm compr., ráquis e ramos escabros; espiguetas dispostas em duas fileiras ..........15.1 U. arrecta

1'. Nós e entrenós hirsutos; bainhas foliares denso-hirsutas; lâminas foliares 24,5-60,5 cm compr.; inflorescências de 10-17,5 cm compr., ráquis e ramos hirsutos; espiguetas dispostas em uma fileira ...

15.2 U. brizantha

15.1 Urochloa arrecta (Hack. ex T. Durand \& Schinz) Morrone \& Zuloaga, Darwiniana, 31 (1-4): 69. 1992.

Fig. 6m-o

Plantas perenes, estoloníferas, ca. 1,5 m alt., entrenós e nós glabros. Folhas com bainhas glabras, margens glabras; lígula membranoso-ciliada, ca. $1 \mathrm{~mm}$ compr.; lâminas 7-19×0,5-1,7 cm, linear-lanceoladas, ápice longo-acuminado, base arredondada, simétrica, face adaxial curto-escabra na base, face abaxial glabra, margens escabras, 10 nervuras secundárias. Inflorescências 1-5,8 cm compr., com 4-9 ramos unilaterais espiciformes alternos, pedúnculos 3,5$6 \mathrm{~cm}$ compr., glabros, ráquis, ramos e pedicelos escabros, axilas pubescentes. Espiguetas solitárias, dispostas em 2 fileiras, $3,5 \times 1 \mathrm{~mm}$, oval-elípticas, agudas; gluma inferior $1 \mathrm{~mm}$ compr., oval, obtusa, glabra, margens glabras, 5-nervada; gluma superior $3,2 \mathrm{~mm}$ compr., oval, aguda, glabra, margens glabras, 7-9-nervada; lema inferior estaminado, $3 \mathrm{~mm}$ compr., oval, agudo, glabro, margens glabras, 5-nervado; pálea inferior $3 \mathrm{~mm}$ compr., glabra, margens glabras, 2-nervada; antécio superior 2,8 $\mathrm{mm}$ compr., largoelíptico, obtuso, glabro, transversalmente rugoso, castanho-claro. Frutos não analisados.

Material selecionado: trilha da bapeba, 27.V.2007, fl. A.C. Mota et al. 66 (CEPEC); trilha da torre, 30.VI.2007, fl., A.C. Mota 83 (HUEFS).

Urochloa arrecta difere bastante de $U$. brizantha, tanto por caracteres vegetativos quanto reprodutivos. Ainda em campo, pode-se diferenciálas pelas inflorescências, pois $U$. arrecta apresenta ráquis e ramos apenas escabros e com espiguetas dispostas em duas fileiras, enquanto $U$. brizantha possui ráquis e ramos hirsutos e curto-escabros, e espiguetas dispostas em uma fileira.

Originária da África e introduzida no Brasil, cresce em lugares úmidos e frequentemente alagados (Morrone \& Zuloaga, 1992). Não havia sido citada por Renvoize (1984) nem por Morrone \& Zuloaga (1992) para a Bahia. Portanto, trata-se do primeiro registro dessa espécie para o Estado. $\mathrm{Na}$ área de estudos, forma touceiras nas bordas e em ambientes alterados no entorno da floresta, sob alta luminosidade, florescendo de maio a novembro.

15.2 Urochloa brizantha (Hochst. ex A. Rich.) R.D. Webster, Pan. Austr.: 233. $1987 . \quad$ Fig. 6p-r

Plantas perenes, decumbentes, radicantes nos nós inferiores, ca. 2,5 m alt., entrenós e nós hirsutos. Folhas com bainhas denso-hirsutas, margens ciliadas; lígula membranoso-ciliada, ca. 2 mm compr.; lâminas 24,5-60,5 × 1-1,7 cm, linear-lanceoladas, ápice longo-acuminado, base arredondada, simétrica, face adaxial hirsuta ou apenas na base, face abaxial esparso-piloso, margens curto-escabras, 6-10 nervuras secundárias. Inflorescências 10-17,5 cm compr., com 2-4 ramos unilaterais espiciformes alternos, pedúnculos 15,5-26,5 cm compr., glabros; ráquis, ramos e axilas hirsutos, pedicelos curtoescabros. Espiguetas solitárias, dispostas em 1 fileira, $4,5 \times 2 \mathrm{~mm}$, elípticas, agudas; gluma inferior ca. $2 \mathrm{~mm}$ compr., oval, obtusa, glabra, margens glabras, 1113-nervada; gluma superior ca. $4 \mathrm{~mm}$ compr., largooval, aguda, pilosa na metade superior, margens glabras, 7-nervada; lema inferior neutro, ca. $4 \mathrm{~mm}$ compr., largo-oval, agudo, glabro, margens glabras, 5-nervado; pálea inferior ca. $4 \mathrm{~mm}$ compr., oval, obtusa, glabra, margens glabras, 2-nervada; antécio superior ca. $4 \mathrm{~mm}$ compr., elíptico, agudo, glabro, transversalmente rugoso, castanho-claro. Frutos não analisados.

Material selecionado: trilha da casa de Vitor Becker para centro de pesquisa, 28.II.2008, fl. A.C. Mota 224 (HUEFS). 
Originária da África, Urochloa brizantha ocorre como subespontânea no Brasil, em campos e áreas com ação antrópica (Gouveia-Santos 2001). Na área de estudos, ocorre nas bordas e em ambientes alterados no entorno da floresta, sob alta intensidade luminosa, observada em floração apenas no mês de fevereiro.

\section{Agradecimentos}

À FAPESB (Fundação de Amparo à Pesquisa do Estado da Bahia) o apoio financeiro (processo APR 0218/2008); CAPES (Coodenação de Aperfeiçoamento de Pessoal de Nível Superior) a bolsa de Mestrado concedida à primeira autora; e CNPq (Conselho Nacional de Desenvolvimento Científicoe Tecnológico) o apoio financeiro (Processo 562349/2010-3) e bolsa de Produtividade em Pesquisa $(\mathrm{PQ} 2)$ concedida à segunda autora. Aos proprietários da RPPN Serra Bonita, Vitor Becker e Clemira Souza o apoio logístico, e ao guardaparque Roni o auxílio nas coletas. Ao curadores e funcionários dos herbários consultados o acesso às coleções, em especial ao Dr. André Amorim, curador do CEPEC. À Carla de Lima as ilustrações.

\section{Referências}

Aliscioni, S.S.; Giussani, L.M.; Zuloaga, F.O. \& Kellogg, E.A. 2003. A molecular phylogeny of Panicum (Poaceae: Paniceae): Tests of monophyly and phylogenetic placement within the Panicoideae. American Journal of Botany 90: 796-821.

Boechat, S.C. 2005. O gênero Ichnanthus (Poaceae Panicoideae - Paniceae) no Brasil. Iheringia 60: 189-248.

Boechat, S.C.; Guglieri, A. \& Longhi-Wagner, H.M. 2001a. Eleusine Gaertn. In: Longhi-Wagner, H.M.; Bittrich, V.; Wanderley, M.G.L. \& Shepherd, G.J. (eds.). Poaceae - Flora fanerogâmica do estado de São Paulo. Vol. 1. Hucitec, São Paulo. Pp. 62-64.

Boechat, S.C. \& Lerina, R. 2001. IchnanthusP. Beauv. In: Longhi-Wagner, H.M.; Bittrich, V.; Wanderley, M.G.L. \& Shepherd, G.J. (eds.). Poaceae - Flora fanerogâmica do estado de São Paulo. Vol. 1. Hucitec, São Paulo. Pp. 157-163.

Boechat, S.C. \& Longhi-Wagner, H.M. 1995. O gênero Sporobolus (Poaceae: Chloridoideae) no Brasil. Acta Botanica Brasilica 9: 21-86.

Boldrini, I.I. 2001a. Pennisetum Rich. In : Longhi-Wagner, H.M.; Bittrich, V.; Wanderley, M.G.L. \& Shepherd, G.J. (eds.). Poaceae - Flora fanerogâmica do estado de São Paulo. Vol. 1. Hucitec, São Paulo. Pp. 228-231.

Boldrini, I.I. 2001b. Setaria P. Beauv. In: Longhi-Wagner, H.M.; Bittrich, V.; Wanderley, M.G.L. \& Shepherd, G.J. (eds.). Poaceae - Flora fanerogâmica do estado de São Paulo. Vol. 1. Hucitec, São Paulo. Pp. 233-238.
Brasil. 2006. Utilização e proteção da vegetação nativa do Bioma Mata Atlântica, Lei no 11.428, de 22 de dezembro de 2006. Disponível em <http:// www.planalto.gov.br/ccivil_03/_Ato2004-2006/ 2006/Lei/L11428.htm>. Acesso em 20 Mar 2007.

Canto-Dorow, T.S. 2001a. Digitaria Haller In: LonghiWagner, H.M.; Bittrich, V.; Wanderley, M.G.L. \& Shepherd, G.J. (eds.). Poaceae - Flora fanerogâmica do estado de São Paulo. Vol. 1. Hucitec, São Paulo. Pp. 143-149.

Canto-Dorow, T.S. 2001b. O gênero Digitaria Haller (Poaceae-Panicoideae-Paniceae) no Brasil. Tese de Doutorado. Universidade Federal do Rio Grande do Sul, Porto Alegre. 386p.

Canto-Dorow, T.S.; Longhi-Wagner, H.M. \& Valls, J.F.M. 1996. Revisão taxonômica das espécies de Paspalum L. grupo Notata (Poaceae - Paniceae) do Rio Grande do Sul, Brasil. Iheringia, série Botânica 47: 3-44.

Clayton, W.D. \& Renvoize, S.A. 1986. Genera graminum: grasses of the world. Royal Botanic Gardens, Kew. 389p.

Columbus, J.T. ; Cerros-Tlatilpa, R.; Kinney, M.S.; Siqueiros-Delgado, M.E.; Bell, H.L.; Griffith, M.P. \& Refulio-Rodriguez, N.F. 2007. Phylogenetics of Chloridoideae (Gramineae): a preliminary study based on nuclear ribosomal internal transcribed spacer and chloroplast $t r n L-F$ sequences. Aliso 23: 565-579.

Davidse, G. 1978. A systematic study of the genus Lasiacis (Gramineae: Paniceae). Annals of the Missouri Botanical Garden 65: 1133-1254.

Dedecca, D.M. 1956. As espécies brasileiras do gênero Axonopus (Gramineae). Bragantia 15: 251-296.

Gouveia-Santos, A. 2001. Urochloa P. Beauv. In: LonghiWagner, H.M.; Bittrich, V.; Wanderley, M.G.L. \& Shepherd, G.J. (eds.). Poaceae - Flora fanerogâmica do estado de São Paulo. Vol. 1. Hucitec, São Paulo. Pp. 243-245.

Hilu, K.W. \& Alice, L.A. 2001. A phylogeny of Chloridoideae (Poaceae) based on matK sequences. Systematic Botany 26: 386-405.

IBGE - Instituto Brasileiro de Geografia e Estatística. 2004. Flora das restingas do litoral norte da Bahia: Costa dos Coqueiros e Salvador. Projeto Flora/ Fauna, EU / BA, Herbário RADAM Brasil, Salvador.

Longhi-Wagner, H.M. 2001a. Pseudechinolaena Stapf. In: Longhi-Wagner, H.M.; Bittrich, V.; Wanderley, M.G.L. \& Shepherd, G.J. (eds.). Poaceae - Flora fanerogâmica do estado de São Paulo. Vol. 1. Hucitec, São Paulo.Pp. 231-232.

Longhi-Wagner, H.M. 2001b. Chloris Sw. In: LonghiWagner, H.M.; Bittrich, V.; Wanderley, M.G.L. \& Shepherd, G.J. (eds.). Poaceae - Flora fanerogâmica do estado de São Paulo. Vol. 1. Hucitec, São Paulo. Pp. 50-53.

Longhi-Wagner, H.M.; Bittrich, V.; Wanderley, M.G.L. \& Shepherd, G.J. 2001. Poaceae - Flora fanerogâmica do estado de São Paulo. Vol. 1. Hucitec, São Paulo. 292p. 
Mez, C. 1921. Neue Gramineen. Botanische Jahrbücher für Systematik, Pflanzengeschichte und Pflanzengeographie, 56. Beiblatt 125: 8.

MMA - Ministério do Meio Ambiente/SBF - Secretaria de Biodiversidade e Florestas. 2000. Avaliação e ações prioritárias para a conservação da biodiversidade da Mata Atlântica e Campos Sulinos. Conservation International do Brasil, Fundação SOS Mata Atlântica, Fundação Biodiversitas, Instituto de Pesquisas Ecológicas, Secretaria do Meio Ambiente do Estado de São Paulo, SEMAD / Instituto Estadual de Florestas-MG, Brasília. 40p.

Mori, S.A.; Boom, B.M.; Carvalho, A.M. \& Santos, T.S. 1983. Southern Bahian Moist Forests. Botanical Review 49: 1-155.

Mori, S.A.; Silva, L.A.M.; Lisboa, G. \& Coradin, L. 1989. Manual de manejo do herbário fanerogâmico. 2 ed. Centro de Pesquisas do Cacau, Ilhéus, Bahia, 97p.

Morrone, O.; Denham, S.S.; Aliscioni, S.S. \& Zuloaga, F.O. 2008. Parodiophyllochloa, a new genus segregated from Panicum (Paniceae, Poaceae) base on morphological and molecular data. Systematic Botany 33: 66-76.

Morrone, O. \& Zuloaga, F.O. 1992. Revisión de las especies sudamericanas nativas e introducidas de los gêneros Brachiaria e Urochloa (Poaceae: Panicoideae: Paniceae). Darwiniana 31: 43-109.

Mota, A.C., Oliveira, R.P \& Filgueiras, T.S. 2009. Poaceae de uma área de floresta montana no sul da Bahia, Brasil: Bambusoideae e Pharoideae. Rodriguésia 60: 747-770.

Oliveira, R.C. \& Valls, J.F.M. 2001. Paspalum L. In: Longhi-Wagner, H.M.; Bittrich, V.; Wanderley, M.G.L. \& Shepherd, G.J. (eds.). Poaceae - Flora fanerogâmica do estado de São Paulo. Vol. 1. Hucitec, São Paulo. Pp. 191-228.

Oliveira, R.P.; Longhi-Wagner, H.M. \& Giulietti, A.M. 2003. O gênero Ichnanthus (Poaceae: Paniceae) na Chapada Diamantina, Bahia, Brasil. Acta Botanica Brasilica 17: 49-70.

Oliveira, R.P.; Longhi-Wagner, H.M. \& Jardim, J.G. 2006. Diversidade e conservação dos bambus herbáceos (Poaceae: Bambusoideae: Olyreae) da Mata Atlântica, Brasil. In: Almeida, J.G.\& Teixeira, A.A. (orgs). Anais do Simpósio Nacional sobre Bambus. Universidade Federal de Brasília, DF. Pp. 62-66.

Pensiero, J.F. 1999. Las especies sudamericanas del género Setaria (Poaceae, Paniceae). Darwiniana 37: 37-151.

Pensiero, J.F. 2003. Setaria P. Beauv.In: Zuloaga, F.O.; Morrone, O.; Davidse, G.; Filgueiras, T.S.; Peterson, P.M.; Soreng, R.J. \& Judziewicz, E. 2003. Catalogue of New World Grasses (Poaceae): III. Subfamilies Panicoideae, Aristidoideae, Arundinoideae, and Danthonioideae. Contributions from the United States National Herbarium 46: 1-662.
Renvoize, S.A. 1984. The grasses of Bahia. Royal Botanic Gardens, Kew, 301p.

Sánchez-Ken, J.G. \& Clark, L.G. 2010. Phylogeny and a new tribal classification of the Panicoideae s.l. (Poaceae) based on plastid and nuclear sequence data and structural data. American Journal of Botany 97: 1732-1748.

Santos, C.A.G. \& Sano, P.T. 2001. Lasiacis (Griseb.) Hitchc. In: Longhi-Wagner, H.M.; Bittrich, V.; Wanderley, M.G.L. \& Shepherd, G.J. (eds.). Poaceae - Flora fanerogâmica do estado de São Paulo. Vol. 1. Hucitec, São Paulo. Pp. 163-164.

Sede, S.M.; Zuloaga, F.O \& Morrone, O. 2009. Phylogenetic studies in the Paniceae (PoaceaePanicoideae): Ocellochloa, a new genus from the New World. Systematic Botany 34: 684-692.

Sendulsky, T. 1978. Brachiaria: Taxonomy of cultivated and native species in Brazil. Hoehnea 7: 99-139.

Simon, B.K. \& Jacobs, S.W.L. 2003. Megathyrsus, a new generic name for Panicum subgenus Megathyrsus. Austrobaileya 6: 572.

Soderstrom, T.R.; Judziewicz, E.J.L. \& Clark, L.G. 1988. Distribution patterns in neotropical bamboos. In: Vanzolini, P.E. \& Heyer, W.R. (eds.). Proceedings of the neotropical biotic distribution pattern workshop. Academia Brasileira de Ciências, Rio de Janeiro. Pp. 120-156.

SOS Mata Atlantica. 2008. Informações Mata Atlântica. Disponível em <http://www.sosmatatlantica.org.br/ index.php?section=info\&action $=$ mata $>$. Acesso em 20 out 2008.

Thomas, W.W. 2003. Natural vegetation types in southern Bahia. In: Prado, P.I.; Landau, E.C.; Moura, R.T.; Pinto, L.P.S.; Fonseca, G.A.B. \& Alger, K. (orgs.). Corredor de Biodiversidade da Mata Atlântica do Sul da Bahia. Publicação em CD-ROM, Ilhéus, IESB / CI / CABS / UFMG / UNICAMP, Campinas.

Thomas, W.W.; Carvalho, A.M.; Amorim, A.M.; Garrison, J.; Arbelaez, A.L. 1998. Plant endemism in two forests in southern Bahia, Brazil. Biodiversity and Conservation 7: 311-322.

Valls, J.F.M.; Longhi-Wagner, H.M. \& Boldrini, I.I. 2001. Axonopus P. Beauv. In: Longhi-Wagner, H.M.; Bittrich, V.; Wanderley, M.G.L. \& Shepherd, G.J. (eds.). Poaceae - Flora fanerogâmica do estado de São Paulo. Vol. 1. Hucitec, São Paulo. Pp. 129-141.

Zanin, A. 2001. Andropogon L. In: Longhi-Wagner, H.M.; Bittrich, V.; Wanderley, M.G.L. \& Shepherd, G.J. (eds.). Poaceae-Flora fanerogâmica do estado de São Paulo. Vol. 1. Hucitec, São Paulo. Pp. 91-96.

Zanin, A. \& Longhi-Wagner, H.M. 2006. Sinopse do gênero Andropogon L. (Poaceae-Andropogoneae) no Brasil. Revista Brasileira de Botânica 29: 289-299.

Zuloaga, F.O. 1987. Systematics of New Word species of the Panicum (Poaceae: Paniceae). In: Sodestrom, T.R.; Hilu, K.W.; Campbell, C.S. \& Barkworth, M.E. 
(eds.). Grass systematics and evolution. Smithsonian Institution Press. Washington, D.C. Pp. 287-306.

Zuloaga, F.O. \& Sendulsky, T. 1988. A revision of Panicum subgenus Phanopyrum section Stolonifera(Poaceae: Paniceae). Annals of the Missouri Botanical Garden 75: 420-455.

Zuloaga, F.O.; Ellis, R.P. \& Morrone, O. 1993. A revision of Panicum subg.Dichanthelium sect. Dichanthelium (Poaceae: Panicoideae: Paniceae) in Mesoamerica, the West Indies, and South America. Annals of the Missouri Botanical Garden 80: 119-190.

Zuloaga, F.O.; Giussani, L.M. \& Morrone, O. 2007. Hopia, a new monotypic genus segregated from Panicum (Poaceae). Taxon 56: 145-156.
Zuloaga, F.O.; Guglieri, A. \& Longhi-Wagner, H.M. 2001a. Panicum L. In: Longhi-Wagner, H.M.; Bittrich, V.; Wanderley, M.G.L. \& Shepherd, G.J. (eds.). Poaceae - Flora fanerogâmica do estado de São Paulo. Vol. 1. Hucitec, São Paulo. Pp. 168-190.

Zuloaga, F.O.; Guglieri, A. \& Longhi-Wagner, H.M. 2001b. Steinchisma Raf. In: Longhi-Wagner, H.M.; Bittrich, V.; Wanderley, M.G.L. \& Shepherd, G.J. (eds.). Poaceae - Flora fanerogâmica do estado de São Paulo. Vol. 1. Hucitec, São Paulo. Pp.238-239.

Zuloaga, F.O.; Morrone, O.; Vega, A.S. \& Giussani, L.M. 1998. Revisión y análisis cladístico de Steinchisma (Poaceae: Panicoideae: Paniceae). Annals of the Missouri Botanical Garden 85: 631-656.

\section{Lista de excicatas}

Amorim, A. M.: 5188 (II.11.1), 6956 (II-6.2), 6994 (II-5.3), 6998 (II-6.1); Borges, R. A. X.: 268 (II-6.2), 308 (II-7.2), 309 (II-8.2), 325 (II-5.2), 675 (II-5.2); Ferreira, F. M.: 1309 (II-3.2), 1310 (II-10.2), 1311 (II-10.2), 1312 (II-5.3), 1313 (II-8.2), 1314 (II-6.2), s/n (CEPEC 117619) (II-5.1); Lopes, M. M. M.: 834 (II-1.1), 835 (II.11.1), 1300 (II-6.1); Mota, A. C.: 51 (II-10.5), 57 (II-6.2), 59 (II-10.3), 60 (II-10.1), 61 (II-5.3), 63 (II-10.6), 64 (II-8.1), 66 (II-15.1), 67 (I-1.2), 68 (II-13.1), 69 (II-10.4), 71 (II-10.5), 72 (II-5.4), 73 (II-3.2), 74 (II-5.3), 75 (II-8.2), 76 (II-10.2), 77 (II-5.4), 78 (II-8.1), 79 (II-10.1), 80 (II-8.2), 81 (II-10.1), 83 (II-15.1), 84 (II5.2), 174 (II-12.1), 175 (II-5.2), 176 (II-15.1), 177 (II-14.1), 178 (II-9.1), 179 (II-1.1), 180 (II-2.1), 181 (I-1.1), 182 (I-3.1), 183 (II10.7), 184 (II-8.2), 185 (II-10.5), 186 (II-10.1), 187 (II-10.2), 189 (II-10.6), 190 (II-10.2), 191 (II-3.1), 192 (II-3.2), 193 (II-4.2), 194 (II-5.3), 196 (II-10.2), 197 (II-8.2), 198 (II-10.3), 204 (II-10.4), 205 (II-6.2), 206 (II-14.1), 207 (I-3.1), 208 (II-10.1), 209 (II-5.3), 210 (II10.2), 211 (II-10.5), 212 (II-5.3), 213 (II-5.2), 214 (II-12.1), 215 (II-5.4), 216 (II-8.2), 217 (II-5.4), 218 (II-10.5), 219 (II-4.1), 220 (II-3.2), 224 (II-15.2), 225 (II-10.3), 226 (II-5.3), 227 (II-8.2), 228 (II-10.2), 230 (II-5.4), 232 (II-5.3), 233 (II-7.1), 234 (II-9.1), 235 (I-2.1), 236 (II-4.3), 237 (II-4.3), 238 (II-5.3), 241 (II-6.1), 242 (II-4.2), 243 (II-10.2), 244 (II-10.1), 245 (II-3.2), 246 (II-10.5), 247 (II-5.3), 248 (II8.2), 249 (II-10.2), 251 (II-6.1), 252 (II-13.1), 253 (II-5.3), 254 (II-5.3), 255 (II-5.4), 257 (II-9.1); Oliveira, R. P.: 1229 (II-3.2), 1237 (II4.3), 1231 (II-5.3), 1228 (II-7.2), 1230 (II-10.1), 1232A (II-10.3), 1232B (II-10.5), 1234 (II-7.1), 1239 (II-6.1). 